\title{
Photodegradation of Polyphenols and Aromatic Amines in Olive Mill Effluents with Ni Doped C/TiO
}

\author{
Delia Teresa Sponza and Rukiye Oztekin \\ Department of Environmental Engineering, Engineering Faculty, Dokuz Eylül University, Tinaztepe Campus, \\ Buca, 35160 Izmir, Turkey \\ Correspondence should be addressed to Delia Teresa Sponza; delya.sponza@deu.edu.tr
}

Received 24 October 2014; Accepted 13 January 2015

Academic Editor: Ronaldo F. do Nascimento

Copyright (C) 2015 D. T. Sponza and R. Oztekin. This is an open access article distributed under the Creative Commons Attribution License, which permits unrestricted use, distribution, and reproduction in any medium, provided the original work is properly cited.

\begin{abstract}
Magnetic nickel coated carbon based titanium dioxide $\left[\mathrm{C} / \mathrm{TiO}_{2} / \mathrm{Ni}\right]$ nanocomposites were used for photodegradation of polyphenols and total aromatic amines (TAAs) metabolites from olive mill wastewaters (OMW) at different operational conditions such as different mass ratios of $\mathrm{C}, \mathrm{TiO}_{2}$, and $\mathrm{Ni}(1 \% / 2 \% / 5 \% ; 5 \% / 1 \% / 2 \%$; and $2 \% / 5 \% / 1 \%)$, being at increasing photodegradation times $(15,30,45,60,75,120$, and $180 \mathrm{~min})$, photocatalyst concentrations $\left(100,250,500\right.$, and $\left.1000 \mathrm{mg} \mathrm{L}^{-1}\right)$, pH values $(3.5,4.0,7.0$, and 10.0$)$ and temperatures $\left(15^{\circ} \mathrm{C}, 25^{\circ} \mathrm{C}, 50^{\circ} \mathrm{C}\right.$, and $\left.80^{\circ} \mathrm{C}\right)$, and being under $300 \mathrm{~W}$ ultraviolet (UV) and $30 \mathrm{~W}$ sunlight irradiation. Under the optimized conditions, at $\mathrm{pH}=7.0$, at $500 \mathrm{mg} \mathrm{L}^{-1} \mathrm{C} / \mathrm{TiO}_{2} / \mathrm{Ni}$ nanocomposite, under $300 \mathrm{~W} \mathrm{UV}$ light, after $60 \mathrm{~min}$, at $25^{\circ} \mathrm{C}$, the maximum $\mathrm{COD}_{\text {dissolved }}$, total phenol, and TAAs removals were $99 \%, 90 \%$, and $96 \%$, respectively. Photodegradation removals in the OMW under sunlight and being lower than those under UV light.
\end{abstract}

\section{Introduction}

Photocatalysis has been recognized as a potential technique for degradation process, which is being widely applied as one of the most effective methods for wastewater treatment [1]. For instance, it is widely applied as a useful technique for destruction of organic pollutants $[2,3]$. $\mathrm{TiO}_{2}$ semiconductor in anatase form is often used as photocatalyst for water purification from pollutants because of its stability, nontoxicity, and relatively satisfied activity $[2,3]$. The high surface area-to-volume ratio of $\mathrm{TiO}_{2}$ nanoparticles, however, results in their aggregation $[2,3]$. To improve the photocatalytic activity of traditional $\mathrm{TiO}_{2}$, there are a variety of novel visible-light-responsive photocatalysts developed and those photocatalysts showed better catalytic activity $[2,3]$. Meanwhile, doped $\mathrm{TiO}_{2}$ photocatalysts $[4,5]$ and composite photocatalysts [6-8] were taken into consideration for the treatment of some dyes and pollutants [9]. $\mathrm{TiO}_{2}$-C hybrids are some of the most extensively investigated and most promising materials to improve the photocatalytic performance of $\mathrm{TiO}_{2}$ because a variety of carbon materials can be tailor-made to meet the demands of $\mathrm{TiO}_{2}$ as a photocatalyst [10]. In addition, the lightweight, nonpolar, nonreactive, and nontoxic nature of carbon materials and the easy separation of the materials from water are attractive in wastewater treatment [10]. In recent years, there has been growing interest in hybridizing carbon nanostructures such as carbon nanotubes (C) [8] and graphene $[9,10]$ with $\mathrm{TiO}_{2}$ to enhance the photocatalytic performance. The main purpose of carbon materials in the nanocomposite is to transfer photogenerated electrons from $\mathrm{TiO}_{2}$ to suppress the recombination for effective charge separation [9]. Zhang [11] found that $\mathrm{TiO}_{2} / \mathrm{Ni}$ composites have the functions of both $\mathrm{TiO}_{2}$ and $\mathrm{Ni}$ [11]. The photocatalytic and biocompatibility studies show that this $\mathrm{TiO}_{2} / \mathrm{Ni}$ composite remains the outstanding photocatalytic activity for organic pollutant decomposition and the biocompatibility of $\mathrm{TiO}_{2}$ [11]. Lin et al. [12] investigated the hydrogenation of nitrobenzene in water by using $\mathrm{Ni} / \mathrm{TiO}_{2}$ catalyst. This catalyst has been used as an effective photocatalyst for decomposition of organic pollutants [11]. Pirkarami et al. [13] found 70\% Reactive Red 19, 75\% Acid Orange 7, and 74\% Acid Red 18 removals with $30 \mathrm{mg} \mathrm{L}^{-1}$ Nano- $\mathrm{Ni}-\mathrm{TiO}_{2}$ photocatalyst at $\mathrm{pH}=7.0$ and $25^{\circ} \mathrm{C}$. Shao et al. [10] studied the photocatalytic degradation of methylene blue $(\mathrm{MB})$ dye with the addition 
of photocatalyst carbon-based anatase-type $\mathrm{TiO}_{2}\left(\mathrm{TiO}_{2}-\mathrm{C}\right)$ hybrid aerogel nanocomposites. The photocatalytic degradation removal at darkness condition was found as $33 \%$ for $\mathrm{MB}$ removal while the $\mathrm{MB}$ photodegradation removal was found as $98 \%$, at $500 \mathrm{~W}$ UV light, after $150 \mathrm{~min}$ at $\mathrm{TiO}_{2} / \mathrm{C}$ mass ratio of 0.902 , at $25^{\circ} \mathrm{C}$. The $\mathrm{Ni} / \mathrm{TiO}_{2}$ photocatalysts with a content of $\mathrm{Ni}$ about $1.5 \mathrm{~mol} \%$ photodegraded $0.025 \mathrm{~g} \mathrm{~L}^{-1}$ of methyl orange with a removal efficiency of $87 \%$ [14]. On the other hand, $\mathrm{C} / \mathrm{Ni} / \mathrm{TiO}_{2}$ nanocomposite is a new class of photocatalyst in $\mathrm{CO}_{2}$ photoreduction under visible light irradiation [15]. Gondal et al. [9] found $81 \%$ removal efficiency for methyl orange by using $0.5 \mathrm{~g} \mathrm{~L}^{-1} \mathrm{C}_{10} \% / \mathrm{TiO}_{2} / \mathrm{Ni}$ under $6 \mathrm{~W} \mathrm{UV} \mathrm{light}(\lambda=464 \mathrm{~nm})$, at $0.4 \mathrm{~g} \mathrm{~L}^{-1}$ initial $\mathrm{Ni}$ concentration, and $\mathrm{C} / \mathrm{TiO}_{2}$ ratio of 0.08 ratio, after $120 \mathrm{~min}$, at $27^{\circ} \mathrm{C}$, respectively. This nanocomposite is suitable for photodegradation of polyphenols and TAAs metabolites in the OMW. The photogenerated electron and hole may recombine if there are no suitable active/reaction sites available on the surface of the light-harvesting semiconductor [9].

Wastewater arising from olive processing is one of the strongest industrial effluents, with chemical oxygen demand (COD) values of up to $220 \mathrm{~g} \mathrm{~L}^{-1}$ and corresponding biochemical oxygen demand (BOD) values of up to $100 \mathrm{~g} \mathrm{~L}^{-1}$. Besides its strong organic content $\left(\mathrm{BOD}_{5} 35-110 \mathrm{~g} \mathrm{~L}^{-1}\right.$, COD $45-$ $170 \mathrm{~g} \mathrm{~L}^{-1}$, suspended solids (SS) 1-9 $\mathrm{g} \mathrm{L}^{-1}$ ), olive mill wastewater (OMW) contains high concentrations of recalcitrant compounds such as lignins and tannins, which give it a characteristic dark color (52 270-180 $000 \mathrm{mg} \mathrm{L}^{-1}$ Pt-Co units), but, most importantly, it contains phenolic compounds and long-chain fatty acids which are toxic to microorganisms and plants. The concentration of phenolic compounds in OMW varies greatly from 0.5 to $24 \mathrm{~g} \mathrm{~L}^{-1}$. The high recalcitrant organic load and the associated toxicity require the treatment of OMW. In recent years, there has been growing interest in oxidation and advanced oxidation processes for the treatment of olive mill wastewater. Ozone is a powerful oxidising agent which attacks the compounds containing aromatic rings and double bonds and breaks them down. Small COD reductions of $18-20 \%$ were observed after $2 \mathrm{~h}$ of ozonation of OMW with an initial COD of $10 \mathrm{~g} \mathrm{~L}^{-1}$. A number of physical, chemical, and biological treatment methods have been reported in literature, including flotation and sedimentation [16], sand filtration [17, 18], ozonation [19], membrane filtration [2022 ], neutralization with addition of acid, advanced chemical oxidation (Fenton reaction) $[23,24]$, adsorption by activated carbon, and aerobic and anaerobic digestions [25-27] for the removal of the OWW. These methods, however, are limited because they are too expensive to find a wide application and ineffective in meeting stringent effluent standards and could result in huge amount of sludge. The utilization of photocatalysis approach with different nanoparticles for OMW treatment has been successfully reported $[28,29]$. However, to the best of our knowledge, there have been no reports on the application of $\mathrm{C} / \mathrm{Ni} / \mathrm{TiO}_{2}$ nanocomposites photodegradation technology on the removal of contaminants from the OMW wastewater.

The aim of this study was the synthesis of PAC on $\mathrm{Ni} / \mathrm{TiO}_{2}$ as a new class of photocatalyst for the removal pollutants in the OMW (COD components, polyphenols, and TAAs metabolites). The effects of mass ratios of $\mathrm{C} / \mathrm{TiO}_{2} / \mathrm{Ni}$ $(1 \% / 2 \% / 5 \% ; 5 \% / 1 \% / 2 \%$; and $2 \% / 5 \% / 1 \%)$, the effects of increasing concentrations of $\mathrm{C} / \mathrm{TiO}_{2} / \mathrm{Ni}$ nanocomposites $\left(100,250,500\right.$, and $\left.1000 \mathrm{mg} \mathrm{L}^{-1}\right)$, increasing photoretention times $(15,30,45,60,75,120$, and $180 \mathrm{~min})$, increasing $\mathrm{pH}$ values $(3.5,4.0,7.0$, and 10.0), and increasing temperatures (15, 25,50 , and $80^{\circ} \mathrm{C}$ ) on the pollutant parameters of OMW were studied at $300 \mathrm{~W}$ UV light and at $30 \mathrm{~W}$ sunlight irradiations.

\section{Material and Methods}

2.1. Raw Wastewater. The characterization of raw OMW taken from the influent of olive oil production industry in İzmir, Turkey, is given in Table 1. This plant is operated with a three-phase olive oil extraction process.

2.2. Preparation of $\mathrm{C} / \mathrm{TiO}_{2} / \mathrm{Ni}$ Photocatalyst. Masses of $3.5 \mathrm{~g}$ of $\mathrm{TiO}_{2}, 3.980 \mathrm{~g}$ of $\mathrm{Ni}(\mathrm{Ac})_{2}$, and $2 \mathrm{~g}$ of activated carbon were weighed, where the mass ratios of $\mathrm{PAC}$ and $\mathrm{TiO}_{2}$ are $1 \%$, $2 \%$, and $5 \%$, respectively. These three mixed raw materials with the designed proportion were grounded with an agate mortar for $30 \mathrm{~min}$ and then sintered in a crucible under $\mathrm{N}_{2}$ (g) atmosphere at $400^{\circ} \mathrm{C}$ for $2 \mathrm{~h}$, with the temperature rise rate of $20^{\circ} \mathrm{C} \mathrm{min}^{-1}$. These samples were obtained after annealing and cooling down to the room temperature. The asprepared composite was named according to the preparation conditions as illustrated by " $\mathrm{C} / \mathrm{TiO}_{2} / \mathrm{Ni}^{\prime}$ ", indicating that " $\mathrm{C}$ ", " $\mathrm{TiO}_{2}$ " are the raw materials of $\mathrm{PAC}$ and $\mathrm{TiO}_{2}$ powders with anatase phase. The mass ratios of $\mathrm{PAC} / \mathrm{TiO}_{2} / \mathrm{Ni}$ were adjusted as $1 \% / 2 \% / 5 \% ; 5 \% / 1 \% / 2 \%$; and $2 \% / 5 \% / 1 \%$, respectively.

2.3. X-Ray Diffraction Analysis. XRD patterns of the samples were carried out using a D/Max-2400 Rigaku X-ray powder diffractometer operated in the reflection mode with $\mathrm{Cu} \mathrm{Ka}$ $(\lambda=0.15418 \mathrm{~nm})$ radiation through scan angle $(2 \theta)$ from $10^{\circ}$ to $80^{\circ}$.

2.4. Scanning Electron Microscopy (SEM) Analysis. The morphological structures of the $\mathrm{C} / \mathrm{TiO}_{2} / \mathrm{Ni}$ nanocomposites before photocatalytic degradation with UV and sunlight irradiations and after photocatalytic degradation with UV and sunlight irradiations were observed by means of a SEM.

2.5. Photocatalytic Degradation Reactor. A 2 L cylinder quartz glass reactor was used for the photodegradation experiments in the OMW under $300 \mathrm{~W}$ UV and $30 \mathrm{~W}$ sunlight irradiations, at different operational conditions. $1000 \mathrm{~mL}$ OMW was filled for experimental studies and the photocatalyst was added to the cylinder glass reactor. The reactor was exposed to the sunlight between hours 11.00 and 16.00 in a day during July. The sunlight power was measured with a Zeikon luminometer where the light power was around $30 \mathrm{~W}$ at the times mentioned above. The photocatalytic reaction was operated with constant stirring during the photocatalytic degradation process under UV and sunlight irradiations. The temperature was controlled with an automatic temperature changing heater inside the photoreactor. The temperature 
TABLE 1: Characterization values of OMW at $\mathrm{pH}=4.5$ ( $n=3$, mean values).

\begin{tabular}{|c|c|c|c|}
\hline \multirow{2}{*}{ Parameters } & \multicolumn{3}{|c|}{ Values } \\
\hline & Minimum & Medium & Maximum \\
\hline$\overline{\mathrm{pH}} \mathrm{H}_{0}$ & 4 & 4.4 & 4.8 \\
\hline $\mathrm{DO}_{0}\left(\mathrm{mg} \mathrm{L}^{-1}\right)$ & 0.01 & 0.06 & 0.11 \\
\hline $\mathrm{ORP}(\mathrm{mV})$ & +122 & +128.5 & +135 \\
\hline TSS $\left(\mathrm{mg} \mathrm{L}^{-1}\right)$ & 55.1 & 57.65 & 60.2 \\
\hline $\mathrm{COD}_{\text {total }}\left(\mathrm{mg} \mathrm{L}^{-1}\right)$ & 99130 & 112270 & 125410 \\
\hline $\mathrm{COD}_{\text {dis }}\left(\mathrm{mg} \mathrm{L}^{-1}\right)$ & 87200 & 102275 & 117350 \\
\hline $\mathrm{COD}_{\text {inert }}\left(\mathrm{mg} \mathrm{L}^{-1}\right)$ & 32460 & 57230 & 82000 \\
\hline $\mathrm{BOD}_{5}\left(\mathrm{mg} \mathrm{L}^{-1}\right)$ & 64500 & 82030 & 99560 \\
\hline $\mathrm{BOD}_{5} / \mathrm{COD}_{\text {dis }}$ & 0.3 & 0.6 & 0.9 \\
\hline Total N $\left(\mathrm{mg} \mathrm{L}^{-1}\right)$ & 198 & 259 & 320 \\
\hline $\mathrm{NH}_{4}-\mathrm{N}\left(\mathrm{mg} \mathrm{L}^{-1}\right)$ & 25.2 & 32.2 & 39.1 \\
\hline $\mathrm{NO}_{3}-\mathrm{N}\left(\mathrm{mg} \mathrm{L}^{-1}\right)$ & 42 & 55 & 68 \\
\hline $\mathrm{NO}_{2}-\mathrm{N}\left(\mathrm{mg} \mathrm{L}^{-1}\right)$ & 19.3 & 24.2 & 29.1 \\
\hline Total P $\left(\mathrm{mg} \mathrm{L}^{-1}\right)$ & 496 & 638.7 & 781.4 \\
\hline $\mathrm{PO}_{4}-\mathrm{P}\left(\mathrm{mg} \mathrm{L}^{-1}\right)$ & 352 & 456.1 & 560.1 \\
\hline \multicolumn{4}{|l|}{ Phenol metabolites $\left(\mathrm{mg} \mathrm{L}^{-1}\right)$} \\
\hline Catechol & 3 & 16 & 29 \\
\hline 4-Methyl catechol & 7 & 19 & 31 \\
\hline 2-PHE & 2 & 5 & 8 \\
\hline 3-PHE & 2 & 9 & 16 \\
\hline TAAs $\left(\mathrm{mg} \mathrm{L}^{-1}\right)$ & 1240 & 1905 & 2570 \\
\hline \multicolumn{4}{|l|}{ Individual TAAs $\left(\mathrm{mg} \mathrm{L}^{-1}\right)$} \\
\hline 2,4,6-trimethylaniline & 49 & 120 & 190 \\
\hline Aniline & 42 & 108 & 174 \\
\hline o-Toluidine & 27 & 94 & 161 \\
\hline o-Anisidine & 48 & 92 & 135 \\
\hline Dimethylalanine & 11 & 51 & 90 \\
\hline Ethylbenzene & 20 & 71 & 122 \\
\hline Durene [3,6-bis(dimethylamino)] & 34 & 100 & 123 \\
\hline
\end{tabular}

was adjusted to the desired level and it was studied at constant temperatures of $15,25,50$, and $80^{\circ} \mathrm{C}$ for desired time intervals. The $\mathrm{pH}$ of the OMW was adjusted to asidic, notral, and alkaline with $1 \mathrm{~N} \mathrm{NaOH}$ and $1 \mathrm{~N} \mathrm{HCl}$. The schematic configuration of the photocatalytic reactor was illustrated in Figure 1. A volume of $10 \mathrm{~mL}$ of the reacting solution was sampled and centrifugated (at $10000 \mathrm{rpm}$ ) at different time intervals.

2.6. Experimental Chemicals. Nano- $\mathrm{TiO}_{2}$, nano- $\mathrm{Ni}(\mathrm{Ac})_{2}$, and PAC were purchased from Merck, (Germany). Helium, $\mathrm{He}$ (g) (GC grade, 99.98\%), and nitrogen, $\mathrm{N}_{2}$ (g) (GC grade, 99.98\%), were purchased from Linde (Germany). Catechol (99\%), tyrosol (99\%), quercetin (99\%), caffeic acid (99\%), 4-methyl catechol (99\%), 2-phenyl-phenol (2-PHE) (99\%), 3-phenyl-phenol (3-PHE) (99\%), 2,4,6 trimethylaniline (99\%), aniline (99\%), o-toluidine (99\%), o-anisidine (99\%), dimethylaniline (99\%), ethylbenzene (99\%), and durene [3,6-bis(dimethylamino)] (99\%) were purchased from Aldrich (Germany).
2.7. Analytical Methods. The $\mathrm{pH}$ values, $\mathrm{T}\left({ }^{\circ} \mathrm{C}\right)$, ORP, DO, $\mathrm{BOD}_{5}, \mathrm{COD}_{\text {total }}, \mathrm{COD}_{\text {dissolved }}$, total suspended solids (TSS), total- $\mathrm{N}, \mathrm{NH}_{3}-\mathrm{N}, \mathrm{NO}_{3}-\mathrm{N}, \mathrm{NO}_{2}-\mathrm{N}$, total-P, and $\mathrm{PO}_{4}-\mathrm{P}$ measurements were monitored following the standard methods 2310, 2320, 2550, 2580, 4500-O, 5210 B, 5220 D, 2540 $\mathrm{D}, 4500-\mathrm{N}, 4500-\mathrm{NH}_{3}, 4500-\mathrm{NO}_{3}, 4500-\mathrm{NO}_{2}$, and $4500-$ $\mathrm{P}$ [30]. Inert COD was measured according to glucose comparison method [31]. 2,4,6 trimethylaniline, aniline, otoluidine, dimethylaniline, ethylbenzene, and durene $[3,6$ bis(dimethylamino)] were identified as TAAs were identified with a high-pressure liquid chromatography (HPLC) (Agilent-1100) with a C-18 reverse phase HPLC column, $(25 \mathrm{~cm} \times 4.6 \mathrm{~mm} \times 5 \mu \mathrm{m}$, Ace $5 \mathrm{C}-18)$. o-Anisidine was measured in a HPLC (Agilent-1100) with a UV detector at a mobile phase of $35 \%$ acetonitrile/ $65 \% \mathrm{H}_{2} \mathrm{O}$ at a flow rate

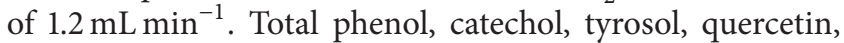
caffeic acid, 4-methyl catechol, 2-PHE, and 3-PHE (HPLC, Agilent-1100) with a Spectra system model SN4000 pump and Asahipak ODP-506D column $(150 \mathrm{~cm} \times 6 \mathrm{~mm} \times 5 \mu \mathrm{m})$.

Irradiations of $300 \mathrm{~W}$ UV light power and $30 \mathrm{~W}$ sunlight power were used for the photocatalytic degradation of 


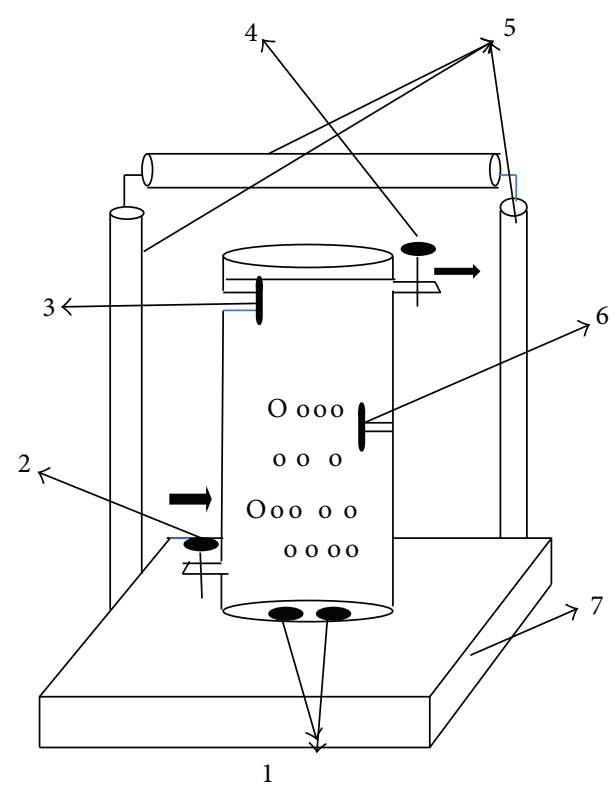

FIgURE 1: The shematic configuration of the photocatalytic reactor (1) magnets, (2) the inlet of OMW, (3) heater for temperature adjustment, (4) the outlet of OMW, (5) UV or sunlight lamps [each one of UV $(100 \mathrm{~W} * 3)$ or sunlight $(30 \mathrm{~W})]$, (6) $\mathrm{pH}$ meter, (7) magnetic stirrer, respectively.

the pollutant parameters in the OMW, at different $\mathrm{pH}$ values (3.5, 4.0, 7.0, and 10.0), different temperatures $\left(15,25^{\circ} \mathrm{C}, 50^{\circ} \mathrm{C}\right.$, and $\left.80^{\circ} \mathrm{C}\right)$, different retention times $(15,30,45,60,75,120$, and $180 \mathrm{~min}$ ), and different $\mathrm{C} / \mathrm{TiO}_{2} / \mathrm{Ni}$ nanocomposite photocatalyst concentrations $\left(100,250,500\right.$, and $\left.1000 \mathrm{mg} \mathrm{L}^{-1}\right)$.

All experiments were carried out three times and the results were given as the means of triplicate samplings.

\section{Results and Discussion}

3.1. XRD Analysis Results. The measured XRD patterns of prepared $\mathrm{C} / \mathrm{TiO}_{2} / \mathrm{Ni}$ nanocomposites with mass ratios of $1 \% / 2 \% / 5 \% ; 5 \% / 1 \% / 2 \%$; and $2 \% / 5 \% / 1 \%$, respectively, are shown in Figure 2. The main diffraction peaks of various products can be ascribed to anatase $\mathrm{TiO}_{2}$, while the peaks at $2 \mathrm{~h}=26.5$ for the graphite-like carbon can also be detected once the $\mathrm{C} / \mathrm{TiO}_{2} / \mathrm{Ni}$ mass ratio was $1 \% / 2 \% / 5 \%$. The metal $\mathrm{Ni}$ species is high when the $\mathrm{C} / \mathrm{TiO}_{2} / \mathrm{Ni}$ mass ratio was $5 \% / 1 \% / 2 \%$. C species can be seen from the XRD pattern, and the nanocomposites with $\mathrm{C} / \mathrm{TiO}_{2} / \mathrm{Ni}$ mass ratio of $2 \% / 5 \% / 1 \%$, $\mathrm{TiO}_{2}$, show the relative diffraction peaks, implying that part of $\mathrm{TiO}_{2}$ might be oxidized and/or lost during the preparation process.

3.2. SEM Analysis Results. Figure 3(a) is a SEM image of mixture of $\mathrm{C} / \mathrm{Ni} / \mathrm{TiO}_{2}$. The microparticles are essentially spherical in shape and have a narrow size distribution of $0.8-1.0 \mu \mathrm{m}$ before photocatalytic oxidation. Figure 3(b) indicates that the core-shell $\mathrm{Ni} / \mathrm{TiO}_{2}$ composite was coated with polyphenols and aromatic amines.

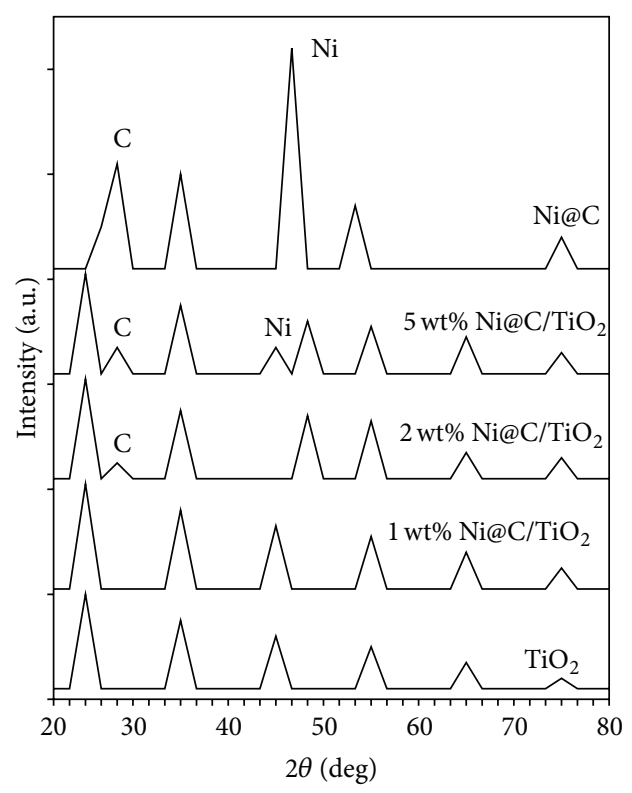

FIgURE 2: The measured XRD patterns of prepared $\mathrm{C} / \mathrm{TiO}_{2} / \mathrm{Ni}$ nanocomposites with mass ratios of $1 \% / 2 \% / 5 \% ; 5 \% / 1 \% / 2 \%$, and $2 \% / 5 \% / 1 \%$, respectively.

3.3. FTIR Analysis Results. The FTIR spectra of C-TiO samples are shown in Figure 4. The peaks at about 3400 and $1630 \mathrm{~cm}^{-1}$ with similar intensities are associated with the stretching vibrations of water molecules, including hydroxyl groups and molecular water.

3.4. Effect of Mass Ratios of $\mathrm{Ni} / \mathrm{C} / \mathrm{TiO}_{2}$ on the OMW Pollutant Parameters. The photocatalytic performance of the synthesized catalyst sample which is combined with three different $\mathrm{C} / \mathrm{TiO}_{2} / \mathrm{Ni}$ mass ratios of $1 \% / 2 \% / 5 \%, 5 \% / 1 \% / 2 \%$, and $2 \% / 5 \% / 1 \%$. The maximum photodegradation efficiency was obtained at $2 \% / 5 \% / 1 \%$ mass ratio of $\mathrm{Ni} / \mathrm{C} / \mathrm{TiO}_{2}$ which is the maximum carbon which can act as photosensitizer, absorbing the UV and sun lights, which can inject the photogenerated electrons into $\mathrm{TiO}_{2}$ conduction band as mentioned in the study performed by Zeng et al. [15] (Table 2). In other words, the interfacial behavior between $\mathrm{C}$ and $\mathrm{TiO}_{2}$ may increase the photogenerated electron mobility in $\mathrm{TiO}_{2}$. Meanwhile, the synergetic effect of the intrinsic properties of $\mathrm{Ni}$ and component in the present nanocomposite is also beneficial for the electron transfer in the conduction band to reduce the pollutants (COD, total phenols and TAAs) in the OMW. Approximately similar photodegradation removals were obtained for $\mathrm{Ni} / \mathrm{C} / \mathrm{TiO}_{2}$ mass ratios of $1 \% / 2 \% / 5 \%$ (the removals are very slightly lower than the removal efficiencies at $2 \% / 5 \% / 1 \% \mathrm{C} / \mathrm{TiO}_{2} / \mathrm{Ni}$ mass ratio), since with high $\mathrm{TiO}_{2}$ mass ratio more electrons were activated by production of high $\mathrm{OH}$ radicals resulting in high pollutant photodegradation in the OMW (Table 2). The effect of high Ni mass ratios in the $\mathrm{Ni} / \mathrm{C} / \mathrm{TiO}_{2}$ nanocomposite formation $(5 \% / 1 \% / 2 \%)$ was found to be not so significant. However, higher pollutant photodegradation removals were obtained for this Ni mass ratio (Table 2). The slightly lower photodegradation removals 
TABLE 2: Effect of mass ratios of $\mathrm{C} / \mathrm{TiO}_{2} / \mathrm{Ni}$ nanocomposites $(1 \% / 2 \% / 5 \%, 5 \% / 1 \% / 2 \%$, and $2 \% / 5 \% / 1 \%)$ and increasing retention times on the removals of OMW during photocatalytic degradation, at $500 \mathrm{mg} \mathrm{L}^{-1} \mathrm{C} / \mathrm{TiO}_{2} / \mathrm{Ni}$ nanocomposite, under $300 \mathrm{~W} \mathrm{UV}$ and $30 \mathrm{~W}$ sunlights, at pH $=7.0$, and at $25^{\circ} \mathrm{C}(n=3$, mean values $)$.

\begin{tabular}{|c|c|c|c|c|c|c|c|c|c|}
\hline \multirow{3}{*}{ Retention time (min) } & \multirow{3}{*}{$\mathrm{C} / \mathrm{TiO}_{2} / \mathrm{Ni}$} & \multicolumn{8}{|c|}{ Removal efficiencies (\%) } \\
\hline & & \multicolumn{4}{|c|}{$\begin{array}{c}\text { UV light } \\
\text { Parameters }\left(\mathrm{mg} \mathrm{L}^{-1}\right)\end{array}$} & \multicolumn{4}{|c|}{$\begin{array}{c}\text { Sunlight } \\
\text { Parameters }\left(\mathrm{mg} \mathrm{L}^{-1}\right)\end{array}$} \\
\hline & & $\mathrm{COD}_{\text {total }}$ & $\mathrm{COD}_{\mathrm{dis}}$ & Total phenol & TAAs & $\mathrm{COD}_{\text {total }}$ & $\mathrm{COD}_{\text {dis }}$ & Total phenol & TAAs \\
\hline \multirow{3}{*}{15} & $1 \% / 2 \% / 5 \%$ & 44 & 42 & 38 & 54 & 42 & 39 & 35 & 46 \\
\hline & $2 \% / 5 \% / 1 \%$ & 55 & 53 & 59 & 70 & 54 & 51 & 55 & 68 \\
\hline & $5 \% / 1 \% / 2 \%$ & 50 & 49 & 50 & 52 & 45 & 40 & 44 & 50 \\
\hline \multirow{3}{*}{30} & $1 \% / 2 \% / 5 \%$ & 49 & 45 & 40 & 56 & 46 & 41 & 37 & 48 \\
\hline & $2 \% / 5 \% / 1 \%$ & 57 & 56 & 61 & 72 & 56 & 54 & 59 & 70 \\
\hline & $5 \% / 1 \% / 2 \%$ & 51 & 50 & 52 & 58 & 47 & 44 & 46 & 55 \\
\hline \multirow{3}{*}{45} & $1 \% / 2 \% / 5 \%$ & 53 & 51 & 47 & 67 & 50 & 49 & 43 & 64 \\
\hline & $2 \% / 5 \% / 1 \%$ & 72 & 70 & 67 & 88 & 70 & 67 & 64 & 87 \\
\hline & $5 \% / 1 \% / 2 \%$ & 56 & 55 & 58 & 64 & 51 & 53 & 50 & 61 \\
\hline \multirow{3}{*}{60} & $1 \% / 2 \% / 5 \%$ & 88 & 86 & 82 & 80 & 85 & 83 & 79 & 77 \\
\hline & $2 \% / 5 \% / 1 \%$ & 99 & 99 & 90 & 96 & 96 & 95 & 88 & 91 \\
\hline & $5 \% / 1 \% / 2 \%$ & 90 & 85 & 78 & 82 & 86 & 81 & 75 & 79 \\
\hline \multirow{3}{*}{75} & $1 \% / 2 \% / 5 \%$ & 86 & 85 & 77 & 78 & 83 & 81 & 74 & 75 \\
\hline & $2 \% / 5 \% / 1 \%$ & 97 & 95 & 86 & 95 & 94 & 93 & 80 & 90 \\
\hline & $5 \% / 1 \% / 2 \%$ & 84 & 81 & 73 & 79 & 81 & 76 & 71 & 74 \\
\hline \multirow{3}{*}{120} & $1 \% / 2 \% / 5 \%$ & 85 & 82 & 71 & 75 & 82 & 78 & 68 & 70 \\
\hline & $2 \% / 5 \% / 1 \%$ & 94 & 93 & 79 & 92 & 92 & 91 & 75 & 89 \\
\hline & $5 \% / 1 \% / 2 \%$ & 76 & 73 & 66 & 74 & 73 & 67 & 62 & 71 \\
\hline \multirow{3}{*}{180} & $1 \% / 2 \% / 5 \%$ & 81 & 80 & 67 & 72 & 80 & 75 & 64 & 69 \\
\hline & $2 \% / 5 \% / 1 \%$ & 90 & 89 & 76 & 90 & 89 & 87 & 68 & 88 \\
\hline & $5 \% / 1 \% / 2 \%$ & 74 & 72 & 64 & 71 & 68 & 63 & 59 & 67 \\
\hline
\end{tabular}

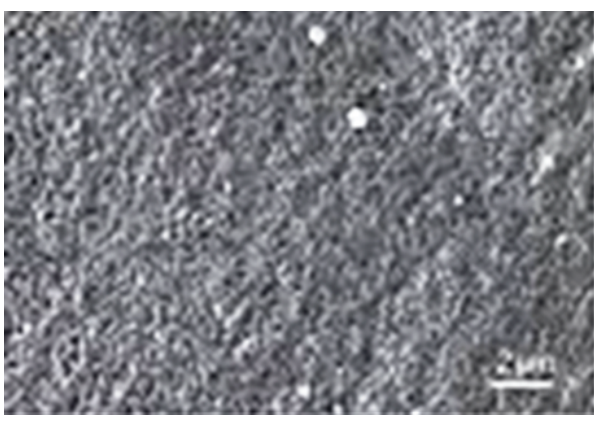

(a)

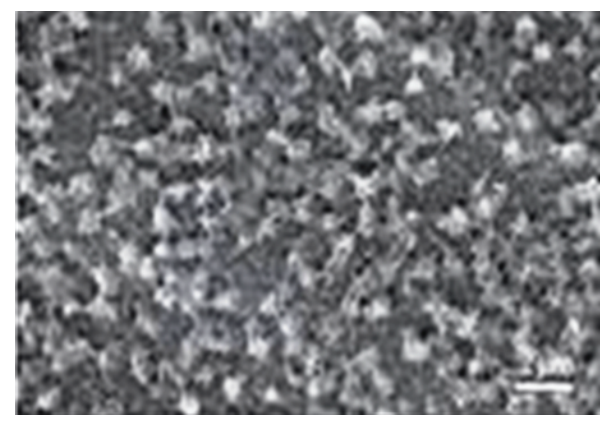

(b)

FIgURE 3: The SEM images of (a) a mixture of $\mathrm{C} / \mathrm{Ni} / \mathrm{TiO}_{2}$ before photocatalytic oxidation and (b) the core-shell Ni/TiO ${ }_{2}$ composite coated with polyphenols and aromatic amines.

can be discussed as follows. The weakly bounded Ni on the stoichiometric $\mathrm{TiO}_{2}$ surface tends to migrate and aggregate to form larger clusters on $\mathrm{TiO}_{2}$ [32]. The electron localization and a different surface chemistry take place during the removal of neutral oxygen from the $\mathrm{TiO}_{2}$ surface and charge transfer between $\mathrm{Ni}$ clusters and $\mathrm{TiO}_{2}$ substrate takes place at the interfaces. The substrate surface treatment influences the oxidation state of $\mathrm{Ni}$. The chemical environment change upon $\mathrm{Ni}$ deposition and the defect structures on $\mathrm{NiO}$ surfaces have been assigned to the $\mathrm{Ni}^{+3}$ species existing on the surface [32]. Generally, modification of $\mathrm{TiO}_{2}$ by $\mathrm{Ni}$ did not enhance the photooxidation of pollutants and obtained results were slightly lower than those obtained using $\mathrm{TiO}_{2}$. The modification of the surface by $\mathrm{Ni}$ is connected with the affordability of $\mathrm{TiO}_{2}$ and the excess of Ni compared to Ti may inhibit the photooxidation (the removals were very slightly lower than the removal efficiencies at $1 \% / 2 \% / 5 \% \mathrm{C} / \mathrm{TiO}_{2} / \mathrm{Ni}$ mass ratio). 


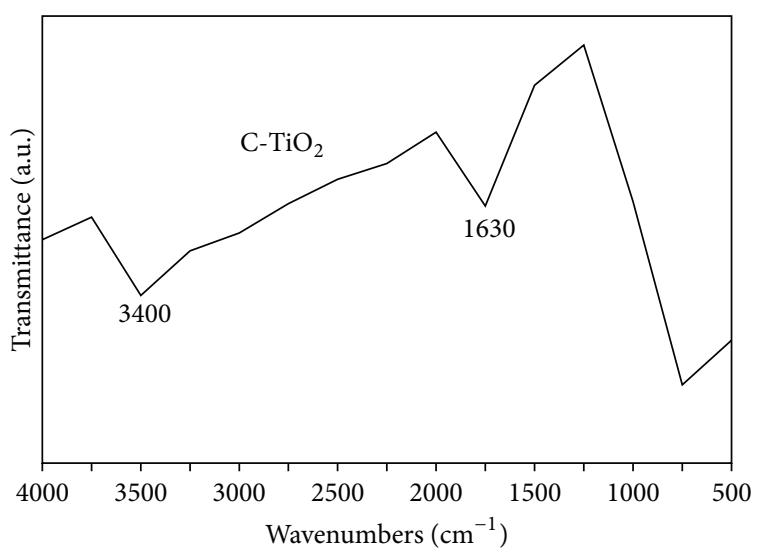

FIgURE 4: The FTIR spectra of $\mathrm{C}-\mathrm{TiO}_{2}$ samples.

3.5. Establishment of the Optimum Retention Time for Photocatalytic Degradation of the Pollutants in the OMW. The effects of increasing retention times $(15,30,45,60,75,120$, and $180 \mathrm{~min}$ ) on the photocatalytic degradation of pollutant parameters in the OMW, under $300 \mathrm{~W} \mathrm{UV}$ and $30 \mathrm{~W}$ sunlight, at $500 \mathrm{mg} \mathrm{L}^{-1} \mathrm{C} / \mathrm{TiO}_{2} / \mathrm{Ni}$ nanocomposites, at $\mathrm{pH}=7.0$, at room temperature $\left(25^{\circ} \mathrm{C}\right)$ are shown in Table 2 . The maximum $\mathrm{COD}_{\text {total }}$, $\mathrm{COD}_{\text {dis }}$, total phenols, and TAAs removals in the OMW were $99 \%, 99 \%, 90 \%$, and $96 \%$, respectively, under $300 \mathrm{~W}$ UV light, at $500 \mathrm{mg} \mathrm{L}^{-1} \mathrm{C} / \mathrm{TiO}_{2} / \mathrm{Ni}$ nanocomposites, at $\mathrm{pH}=7.0$, at $25^{\circ} \mathrm{C}$, after $60 \mathrm{~min}$, respectively (Table 2). The maximum $\mathrm{COD}_{\text {total }}, \mathrm{COD}_{\text {dis }}$, total phenols, and TAAs removals in the OMW were 96\%, 95\%, 88\%, and $91 \%$, respectively, under $30 \mathrm{~W}$ sunlight, at $500 \mathrm{mg} \mathrm{L}^{-1}$ $\mathrm{C} / \mathrm{TiO}_{2} / \mathrm{Ni}$ nanocomposites, at $\mathrm{pH}=7.0$, at $25^{\circ} \mathrm{C}$, after $60 \mathrm{~min}$, respectively (Table 2 ). As the photodegradation times were increased from $15 \mathrm{~min}$ up to $60 \mathrm{~min}$ in the presence of $500 \mathrm{mg} \mathrm{L}^{-1} \mathrm{C} / \mathrm{TiO}_{2} / \mathrm{Ni}$ nanocomposite, photodegradation removals were increased in all pollutant parameters in the OMW under 300 W UV light (Table 2). Similarly, the removal efficiencies increased as the contact time between pollutants and $500 \mathrm{mg} \mathrm{L}^{-1} \mathrm{C} / \mathrm{TiO}_{2} / \mathrm{Ni}$ nanocomposite increased from $15 \mathrm{~min}$ to $60 \mathrm{~min}$ in the OMW, under $30 \mathrm{~W}$ sunlight. On the other hand, the removals of pollutant parameters in the OMW decreased in the same UV and sunlight as the increasing retention times from 75 to $180 \mathrm{~min}$, respectively (Table 2). Low contact times cannot be enough for $\mathrm{OH}$ radical production throughout photooxidation process while high contact times could have decomposed the structure and the pores of $\mathrm{C} / \mathrm{TiO}_{2} / \mathrm{Ni}$ nanocomposite, and the photocatalysts might have been covered completely with the particles of pollutants. Therefore, the maximum removal efficiencies were observed at $60 \mathrm{~min}$ retention time during the experimental studies (Table 2).

\subsection{Effect of Different $\mathrm{C} / \mathrm{TiO}_{2} / \mathrm{Ni}$ Nanocomposite Concentra-} tions on the Photocatalytic Degradation of the Pollutants in the $O M W$. Since the maximum photodegradation removals of $\mathrm{C} / \mathrm{TiO}_{2} / \mathrm{Ni}$ nanocomposite were obtained with mass ratio of $2 \% / 5 \% / 1 \%$, the studies were performed with this form of the nanocomposite synthesized under laboratory conditions. The rate of photocatalytic reaction and the removal of pollutants in the OMW are strongly influenced by the amount of the photocatalyst. Heterogeneous photocatalytic reactions are known to show proportional increase in photodegradation with catalyst loading. Generally, in any given photocatalytic application, the optimum catalyst concentration must be determined in order to avoid excess usage of catalyst and to ensure the total absorption of efficient photons. As shown in Table 3, four different $\mathrm{C} / \mathrm{TiO}_{2} / \mathrm{Ni}$ nanocomposite concentrations $\left(100,250,500\right.$, and $\left.1000 \mathrm{mg} \mathrm{L}^{-1}\right)$ were used to determine the maximum removals of pollutant parameters (COD components $\left(\mathrm{COD}_{\text {total }}, \mathrm{COD}_{\text {dis }}\right.$, and $\left.\mathrm{COD}_{\text {inert }}\right)$, polyphenols (catechol, tyrosol, quercetin, caffeic acid, 4methyl catechol, 2-PHE, and 3-PHE), and TAAs metabolites (2,4,6 trimethylaniline, aniline, o-toluidine, o-anisidine, dimethylaniline, ethylbenzene, and durene), resp.) in the OMW throughout photocatalytic degradation, under UV and sunlight. The maximum $\mathrm{COD}_{\text {total }}, \mathrm{COD}_{\text {dis }}$, and $\mathrm{COD}_{\text {inert }}$ removals in the OMW were $99 \%, 99 \%$, and $73 \%$, respectively, under $300 \mathrm{~W}$ UV light, at $500 \mathrm{mg} \mathrm{L}^{-1} \mathrm{C} \mathrm{TiO}_{2} / \mathrm{Ni}$ nanocomposite, at $\mathrm{pH}=7.0$, at $25^{\circ} \mathrm{C}$, after $60 \mathrm{~min}$, respectively (Table 3). The maximum removals of total phenols and polyphenols were between 86 and 90\%, under $300 \mathrm{~W}$ UV light, at $500 \mathrm{mg} \mathrm{L}^{-1} \mathrm{C} / \mathrm{TiO}_{2} / \mathrm{Ni}$ nanocomposites, at $\mathrm{pH}=7.0$, at $25^{\circ} \mathrm{C}$, after $60 \mathrm{~min}$, respectively (Table 3 ). The maximum removal efficiencies of TAAs and TAAs metabolites, such as 2,4,6 trimethylaniline, aniline, o-toluidine, o-anisidine, dimethylaniline, ethylbenzene, and durene, in the OMW were between 80 and $96 \%$, under $300 \mathrm{~W}$ UV light, at $500 \mathrm{mg} \mathrm{L}^{-1} \mathrm{C} / \mathrm{TiO}_{2} / \mathrm{Ni}$ nanocomposites, at $\mathrm{pH}=7.0$, at $25^{\circ} \mathrm{C}$, after $60 \mathrm{~min}$, respectively (Table 3 ). On the other hand, the removal efficiencies of pollutant parameters (COD components, polyphenols, and TAAs metabolites) increased as the $\mathrm{C} / \mathrm{TiO}_{2} / \mathrm{Ni}$ nanocomposites concentrations were increased from 100 to $250 \mathrm{mg} \mathrm{L}^{-1}$ under $300 \mathrm{~W}$ UV light. Therefore, the removal efficiencies of the pollutant parameters (COD components, polyphenols, and TAAs metabolites) were slightly decreased from 500 to $1000 \mathrm{mg} \mathrm{L}^{-1} \mathrm{C} / \mathrm{TiO}_{2} / \mathrm{Ni}$ nanocomposites concentrations under $300 \mathrm{~W}$ UV light (Table 3). The observation was that removal efficiency increased as the quantity of the nanocomposite was increased. However, in this study low photodegradation removals were observed with low $\left(100 \mathrm{mg} \mathrm{L}^{-1}\right)$ and high $\left(1000 \mathrm{mg} \mathrm{L}^{-1}\right) \mathrm{C} \mathrm{TiO}_{2} / \mathrm{Ni}$ concentrations. The inhibition effect of over loaded photocatalysts concentrations for the pollutant parameter removals in the OMW was detected. Probably the structural decomposition of photocatalysts and the pore surfaces of photocatalysts might have been covered completely with the particles of pollutant parameters $\left(\mathrm{COD}_{\text {total }}\right.$, $\mathrm{COD}_{\text {dis }}$, total phenols, and TAAs) or other radical species (carbon based radicals, e.g., $\mathrm{CO}_{3}{ }^{\circ}$ radicals, etc.). The effect of photocatalyst quantity can be explained by the fact that decreasing the amount of photocatalyst decreases the number of active sites on the $\mathrm{Ni}-\mathrm{TiO}_{2}$ surface, which in turn decreases the numbers of hydroxyl $\left(\mathrm{OH}^{*}\right)$ and hydroperoxyl $\left(\mathrm{OH}_{2}{ }^{\circ}\right)$ radicals.

The maximum $\mathrm{COD}_{\text {total }}, \mathrm{COD}_{\text {dis }}$, and $\mathrm{COD}_{\text {inert }}$ removals in the OMW were $96 \%, 95 \%$, and $70 \%$, respectively, under $30 \mathrm{~W}$ sunlight, at $500 \mathrm{mg} \mathrm{L}^{-1} \mathrm{C} / \mathrm{TiO}_{2} / \mathrm{Ni}$ nanocomposites, at 
TABLE 3: Effect of increasing $\mathrm{C} / \mathrm{TiO}_{2} / \mathrm{Ni}$ nanocomposite concentrations on the removals of $\mathrm{OMW}$ during photocatalytic degradation, under $300 \mathrm{~W} \mathrm{UV}$ and $30 \mathrm{~W}$ sunlight irradiations, at $\mathrm{pH}=7.0$, and at $25^{\circ} \mathrm{C}$, after $60 \mathrm{~min}(n=3$, mean values).

\begin{tabular}{|c|c|c|c|c|c|c|c|c|}
\hline \multirow{3}{*}{ Parameters $\left(\mathrm{mg} \mathrm{L}^{-1}\right)$} & \multicolumn{8}{|c|}{ Removal efficiencies (\%) } \\
\hline & \multicolumn{4}{|c|}{$\begin{array}{c}\text { UV light } \\
\mathrm{C} / \mathrm{TiO}_{2} / \mathrm{Ni} \text { nanocomposites }\left(\mathrm{mg} \mathrm{L}^{-1}\right)\end{array}$} & \multicolumn{4}{|c|}{$\begin{array}{c}\text { Sunlight } \\
\mathrm{C} / \mathrm{TiO}_{2} / \mathrm{Ni} \text { nanocomposites }\left(\mathrm{mg} \mathrm{L}^{-1}\right)\end{array}$} \\
\hline & 100 & 250 & 500 & 1000 & 100 & 250 & 500 & 1000 \\
\hline $\mathrm{COD}_{\text {total }}$ & 57 & 72 & 99 & 94 & 56 & 70 & 96 & 92 \\
\hline $\mathrm{COD}_{\text {dissolved }}$ & 56 & 70 & 99 & 93 & 54 & 67 & 95 & 91 \\
\hline $\mathrm{COD}_{\text {inert }}$ & 39 & 48 & 73 & 65 & 37 & 46 & 70 & 61 \\
\hline Total phenol & 61 & 67 & 90 & 89 & 59 & 64 & 88 & 85 \\
\hline \multicolumn{9}{|l|}{ Polyphenols } \\
\hline Catechol & 59 & 66 & 87 & 85 & 57 & 63 & 84 & 82 \\
\hline Tyrosol & 58 & 64 & 89 & 86 & 55 & 59 & 87 & 80 \\
\hline Quercetin & 54 & 67 & 90 & 89 & 52 & 64 & 88 & 79 \\
\hline Caffeic acid & 56 & 63 & 88 & 81 & 55 & 61 & 86 & 76 \\
\hline 4-Methyl catechol & 50 & 64 & 89 & 83 & 48 & 62 & 85 & 80 \\
\hline 2-PHE & 57 & 65 & 88 & 86 & 54 & 63 & 82 & 82 \\
\hline 3-PHE & 59 & 67 & 86 & 84 & 56 & 62 & 83 & 81 \\
\hline TAAs & 72 & 88 & 96 & 92 & 70 & 87 & 91 & 90 \\
\hline \multicolumn{9}{|l|}{ TAAs Metabolites } \\
\hline 2,4,6 trimethlyaniline & 53 & 64 & 88 & 84 & 51 & 61 & 85 & 81 \\
\hline Aniline & 58 & 63 & 86 & 82 & 57 & 60 & 83 & 79 \\
\hline o-Toluidine & 59 & 67 & 85 & 81 & 58 & 65 & 81 & 77 \\
\hline o-Anisidine & 48 & 65 & 93 & 89 & 46 & 63 & 90 & 86 \\
\hline Dimethylaniline & 49 & 65 & 95 & 92 & 47 & 60 & 92 & 89 \\
\hline Ethylbenzene & 56 & 67 & 94 & 90 & 55 & 64 & 91 & 88 \\
\hline Durene [3,6-bis(dimethylamino)] & 50 & 62 & 80 & 78 & 48 & 59 & 78 & 75 \\
\hline
\end{tabular}

$\mathrm{pH}=7.0$, at $25^{\circ} \mathrm{C}$, after $60 \mathrm{~min}$, respectively (Table 3 ). The maximum removal efficiencies of total phenols and polyphenols were between 82 and $88 \%$ under $30 \mathrm{~W}$ sunlight, at $500 \mathrm{mg} \mathrm{L}^{-1} \mathrm{C} / \mathrm{TiO}_{2} / \mathrm{Ni}$ nanocomposites, at $\mathrm{pH}=7.0$, at $25^{\circ} \mathrm{C}$, after $60 \mathrm{~min}$, respectively (Table 3 ). The maximum removals of all pollutant parameters in the OMW were between 78 and $92 \%$, under $30 \mathrm{~W}$ sunlight, at $500 \mathrm{mg} \mathrm{L}^{-1} \mathrm{C} / \mathrm{TiO}_{2} / \mathrm{Ni}$ nanocomposites, at $\mathrm{pH}=7.0$, at $25^{\circ} \mathrm{C}$, after $60 \mathrm{~min}$ (Table 3). The result of the photocatalytic degradation removals of the pollutant parameters in the $\mathrm{OMW}$ with $\mathrm{C} / \mathrm{TiO}_{2} / \mathrm{Ni}$ under sunlight showed that the removals were slightly lower than the photocatalytic degradation removals of the pollutant parameters in the OMW under UV light. In addition, the pollutant parameters (COD components, polyphenols, and TAAs metabolites) removal efficiencies were increased from 100 to $250 \mathrm{mg} \mathrm{L}^{-1} \mathrm{C} / \mathrm{TiO}_{2} / \mathrm{Ni}$ nanocomposites concentrations under $30 \mathrm{~W}$ sunlight. However, the removal efficiencies of the pollutant parameters (COD components, polyphenols, and TAAs metabolites) were slightly decreased from 500 to $1000 \mathrm{mg} \mathrm{L}^{-1} \mathrm{C} / \mathrm{TiO}_{2} / \mathrm{Ni}$ nanocomposite concentrations under $30 \mathrm{~W}$ sunlight (Table 3 ). A removal of $87 \%$ of total polyphenols, compared to $58 \%$ removal of COD, was determined after $24 \mathrm{~h}$ exposure to $365 \mathrm{~nm} \mathrm{UV} \mathrm{light} \mathrm{(at} 7.6 \mathrm{~W} \mathrm{~m}^{-2}$ ), at $25^{\circ} \mathrm{C}$, at $\mathrm{pH}=8.0$ [33]. In this study, the $99 \% \mathrm{COD}_{\text {dis }}$ and $90 \%$ total phenol removals (Table 3) are higher than the removals observed by Baransi et al. [33] as mentioned above.

3.7. Establishment of Optimum Temperature Value for Photocatalytic Degradation of the OMW Pollutants with $\mathrm{C} / \mathrm{TiO}_{2} / \mathrm{Ni}$. The effect of increasing temperature values $(15,25,50$, and $80^{\circ} \mathrm{C}$ ) on the photocatalytic degradation of the OMW pollutants was investigated, under $300 \mathrm{~W} \mathrm{UV}$ and $30 \mathrm{~W}$ sunlight, at optimum photocatalyst concentration $\left(500 \mathrm{mg} \mathrm{L}^{-1}\right.$ $\mathrm{C} / \mathrm{TiO}_{2} / \mathrm{Ni}$ nanocomposite), at optimum $\mathrm{pH}$ value $(\mathrm{pH}=$ 7.0 ), at optimum retention time $(60 \mathrm{~min})$. The increasing of temperature values from 15 to $25^{\circ} \mathrm{C}$ showed a raise in the removal efficiencies of OMW pollutants in both UV conditions. The maximum $\mathrm{COD}_{\text {total }}$, $\mathrm{COD}_{\text {dis }}$, total phenols, and TAAs removals in the OMW were $99 \%, 99 \%, 90 \%$, and $96 \%$, respectively, under $300 \mathrm{~W}$ UV light, at $\mathrm{pH}=7.0$, at $25^{\circ} \mathrm{C}$, after $60 \mathrm{~min}$, respectively (Table 4 ). The removal efficiencies of $\mathrm{COD}_{\text {total }}$, $\mathrm{COD}_{\text {dis }}$, total phenols, and TAAs in the OMW were $96 \%, 95 \%, 88 \%$, and $91 \%$, respectively, under $30 \mathrm{~W}$ sunlight, at $500 \mathrm{mg} \mathrm{L}^{-1} \mathrm{C} / \mathrm{TiO}_{2} / \mathrm{Ni}$ nanocomposite, at $\mathrm{pH}=7.0$, at $25^{\circ} \mathrm{C}$, after $60 \mathrm{~min}$, respectively (Table 4 ). The photodegradation removals of the pollutant parameters decreased as the temperature increased from 25 to 50 and to $80^{\circ} \mathrm{C}$ in both types of irradiation light (Table 4). Therefore, 
TABLE 4: Effect of increasing temperature values on the removals of OMW during photocatalytic degradation, at $500 \mathrm{mg} \mathrm{L} \mathrm{C}^{-1} \mathrm{TiO} \mathrm{O}_{2} / \mathrm{Ni}$ nanocomposites, under $300 \mathrm{~W}$ UV and $30 \mathrm{~W}$ sunlight irradiations, after $60 \mathrm{~min}$, at $\mathrm{pH}=7.0$. ( $n=3$, mean values).

\begin{tabular}{|c|c|c|c|c|c|c|c|c|}
\hline \multirow{3}{*}{ Parameters $\left(\mathrm{mg} \mathrm{L}^{-1}\right)$} & \multicolumn{8}{|c|}{ Removal efficiencies (\%) } \\
\hline & \multicolumn{4}{|c|}{$\begin{array}{c}\text { UV light } \\
T\left({ }^{\circ} \mathrm{C}\right)\end{array}$} & \multicolumn{4}{|c|}{$\begin{array}{c}\text { Sunlight } \\
T\left({ }^{\circ} \mathrm{C}\right)\end{array}$} \\
\hline & 15 & 25 & 50 & 80 & 15 & 25 & 50 & 80 \\
\hline $\mathrm{COD}_{\text {total }}$ & 81 & 99 & 96 & 72 & 79 & 96 & 93 & 71 \\
\hline $\mathrm{COD}_{\text {dissolved }}$ & 79 & 99 & 95 & 71 & 76 & 95 & 92 & 68 \\
\hline $\mathrm{COD}_{\text {inert }}$ & 70 & 73 & 68 & 55 & 67 & 70 & 66 & 52 \\
\hline Total phenol & 85 & 90 & 86 & 69 & 82 & 88 & 82 & 65 \\
\hline \multicolumn{9}{|l|}{ Polyphenols } \\
\hline Catechol & 80 & 87 & 85 & 63 & 76 & 84 & 82 & 60 \\
\hline Tyrosol & 82 & 89 & 77 & 65 & 77 & 87 & 71 & 57 \\
\hline Quercetin & 84 & 90 & 85 & 64 & 80 & 88 & 81 & 61 \\
\hline Caffeic acid & 79 & 88 & 86 & 67 & 78 & 86 & 79 & 64 \\
\hline 4-Methyl catechol & 82 & 89 & 79 & 57 & 75 & 85 & 74 & 55 \\
\hline 2-PHE & 80 & 88 & 86 & 68 & 79 & 82 & 80 & 64 \\
\hline 3-PHE & 78 & 86 & 84 & 69 & 76 & 83 & 82 & 63 \\
\hline TAAs & 89 & 96 & 91 & 73 & 85 & 91 & 87 & 67 \\
\hline \multicolumn{9}{|l|}{ TAAs metabolites } \\
\hline $2,4,6$ trimethlyaniline & 80 & 88 & 86 & 71 & 76 & 85 & 84 & 65 \\
\hline Aniline & 76 & 86 & 85 & 70 & 74 & 83 & 82 & 66 \\
\hline o-Toluidine & 75 & 85 & 84 & 68 & 73 & 81 & 83 & 64 \\
\hline o-Anisidine & 82 & 93 & 91 & 65 & 78 & 90 & 86 & 63 \\
\hline Dimethylaniline & 84 & 95 & 90 & 67 & 80 & 92 & 87 & 66 \\
\hline Ethylbenzene & 80 & 94 & 91 & 68 & 77 & 91 & 85 & 62 \\
\hline Durene [3,6-bis(dimethylamino)] & 72 & 80 & 76 & 70 & 69 & 78 & 73 & 66 \\
\hline
\end{tabular}

the optimum operational temperature was selected as $25^{\circ} \mathrm{C}$ (room temperature) for the maximum removals of pollutant parameters in OMW during photocatalytic degradation.

Numerous studies have been conducted to detect the dependence of photocatalytic reaction on the reaction temperature $[34,35]$. Although most of the previous investigations stated that an increase in photocatalytic reaction temperature promotes the recombination of charge carriers and disfavours the adsorption of organic compounds onto the $\mathrm{TiO}_{2}$ surface [36], at $25^{\circ} \mathrm{C}$, more carbon enters into the $\mathrm{Ni} / \mathrm{TiO}_{2}$ composite and the doped carbon content increases, probably, consequently, the absorbance of visible light increases significantly and the band gap energy reduces. When increasing the treating temperature to 50 and $80^{\circ} \mathrm{C}$, the doped carbon was released, resulting in the decreased visible light absorbance. Generally, the photocatalytic activity is proportional to low and high light intensities. At low and high temperatures the visible light absorbance could contribute to the decrease of the photocatalytic activity. Therefore, the enhanced visible light activity at $25^{\circ} \mathrm{C}$ in $\mathrm{C}$-doped $\mathrm{Ni} / \mathrm{TiO}_{2}$ can be partly explained by the broadened light absorbance.

3.8. Establishment of the Optimum $\mathrm{pH}$ Value for Photocatalytic Degradation in the OMW. Table 5 shows the effect of increasing $\mathrm{pH}$ values $(3.5,4.0,7.0$, and 10.0) throughout photocatalytic degradation on the removals of OMW, under
$300 \mathrm{~W}$ UV and $30 \mathrm{~W}$ sunlight, at optimum retention time $(60 \mathrm{~min})$, at room temperature $\left(25^{\circ} \mathrm{C}\right)$, at optimum photocatalyst concentration $\left(500 \mathrm{mg} \mathrm{L}^{-1} \mathrm{C} / \mathrm{TiO}_{2} / \mathrm{Ni}\right.$ nanocomposites). The maximum $\mathrm{COD}_{\text {total }}$, $\mathrm{COD}_{\text {dis }}$, total phenols, and TAAs removals in the OMW were $99 \%, 99 \%, 90 \%$, and $96 \%$, respectively, under $300 \mathrm{~W} \mathrm{UV}$ and $30 \mathrm{~W}$ sunlight, at $500 \mathrm{mg} \mathrm{L}^{-1} \mathrm{C} / \mathrm{TiO}_{2} / \mathrm{Ni}$ nanocomposites, at $\mathrm{pH}=7.0$, at $25^{\circ} \mathrm{C}$, after $60 \mathrm{~min}$, respectively (Table 5 ). The photodegradation removal efficiencies decreased as the $\mathrm{pH}$ was decreased from 7.0 to 3.5 , under both $\mathrm{UV}$ and sun lights, at $500 \mathrm{mg} \mathrm{L}^{-1}$ $\mathrm{C} / \mathrm{TiO}_{2} / \mathrm{Ni}$ nanocomposites, at $25^{\circ} \mathrm{C}$, after $60 \mathrm{~min}$, respectively (Table 5 ). Similarly, the photodegradation removal efficiencies decreased as the $\mathrm{pH}$ was increased from 7 up to 10 for the same operational conditions (Table 5). This phenomenon may be attributed to the fact that, as $\mathrm{pH}$ is neutral, the concentration of $\mathrm{OH}$ ions also increases, thus causing $\mathrm{Ni}-\mathrm{TiO}_{2}$ to generate $\mathrm{OH}^{-}$and $\mathrm{O}^{2-}$ more efficiently. However, it is also seen that the rate of removal diminished for the values beyond $\mathrm{pH}=7.0$. This is possibly because, at higher $\mathrm{pH}$ values, the negatively charged photocatalyst surface repulses the pollutant anions, thereby reducing all pollutant efficiencies in the OMW. The lower photodegradation rate of the phenolic and aromatic compounds at $\mathrm{pH}=$ 10.0 is likely a result of the low adsorption onto the surfaces of $\mathrm{C} / \mathrm{TiO}_{2} / \mathrm{Ni}$ nanocomposites. Another explanation regarding the languor of the process at high $\mathrm{pH}$ levels is the presence 
TABLE 5: Effect of increasing $\mathrm{pH}$ values on the removals of OMW during photocatalytic degradation, at $500 \mathrm{mg} \mathrm{L} \mathrm{C}^{-1} \mathrm{TiO} \mathrm{O}_{2} / \mathrm{Ni}$ nanocomposites, under $300 \mathrm{~W} \mathrm{UV}$ and $30 \mathrm{~W}$ sunlight irradiations, after $60 \mathrm{~min}$, at $25^{\circ} \mathrm{C}(n=3$, mean values).

\begin{tabular}{|c|c|c|c|c|c|c|c|c|}
\hline \multirow{3}{*}{ Parameters $\left(\mathrm{mg} \mathrm{L}^{-1}\right)$} & \multicolumn{8}{|c|}{ Removal efficiencies (\%) } \\
\hline & \multicolumn{4}{|c|}{$\begin{array}{l}\text { UV light } \\
\text { pH values }\end{array}$} & \multicolumn{4}{|c|}{$\begin{array}{l}\text { Sunlight } \\
\text { pH values }\end{array}$} \\
\hline & 3.5 & 4.0 & 7.0 & 10.0 & 3.5 & 4.0 & 7.0 & 10.0 \\
\hline $\mathrm{COD}_{\text {total }}$ & 82 & 98 & 99 & 69 & 80 & 95 & 96 & 66 \\
\hline $\mathrm{COD}_{\text {dissolved }}$ & 80 & 97 & 99 & 66 & 77 & 94 & 95 & 62 \\
\hline $\mathrm{COD}_{\text {inert }}$ & 69 & 71 & 73 & 56 & 68 & 69 & 70 & 53 \\
\hline Total phenol & 86 & 88 & 90 & 65 & 83 & 84 & 88 & 60 \\
\hline \multicolumn{9}{|l|}{ Polyphenols } \\
\hline Catechol & 81 & 85 & 87 & 58 & 75 & 82 & 84 & 55 \\
\hline Tyrosol & 83 & 88 & 89 & 60 & 76 & 84 & 87 & 58 \\
\hline Quercetin & 85 & 87 & 90 & 59 & 79 & 81 & 88 & 56 \\
\hline Caffeic acid & 80 & 86 & 88 & 62 & 78 & 83 & 86 & 59 \\
\hline 4-Methyl catechol & 83 & 87 & 89 & 52 & 74 & 81 & 85 & 50 \\
\hline 2-PHE & 81 & 85 & 88 & 63 & 77 & 80 & 82 & 59 \\
\hline 3-PHE & 79 & 84 & 86 & 65 & 80 & 82 & 83 & 58 \\
\hline TAAs & 90 & 93 & 96 & 68 & 86 & 89 & 91 & 62 \\
\hline \multicolumn{9}{|l|}{ TAAs metabolites } \\
\hline $2,4,6$ trimethlyaniline & 80 & 86 & 88 & 66 & 76 & 83 & 85 & 60 \\
\hline Aniline & 78 & 83 & 86 & 65 & 75 & 81 & 83 & 61 \\
\hline o-Toluidine & 76 & 84 & 85 & 62 & 74 & 80 & 81 & 59 \\
\hline o-Anisidine & 83 & 91 & 93 & 49 & 79 & 88 & 90 & 45 \\
\hline Dimethylaniline & 85 & 93 & 95 & 50 & 81 & 89 & 91 & 48 \\
\hline Ethylbenzene & 82 & 90 & 94 & 60 & 78 & 89 & 91 & 57 \\
\hline Durene [3,6-bis(dimethylamino)] & 73 & 78 & 80 & 64 & 70 & 74 & 78 & 62 \\
\hline
\end{tabular}

of carbonate $\left(\mathrm{CO}_{3}{ }^{2-}\right)$ ions, which could scavenge the $\mathrm{OH}^{\bullet}$, or holes produced on the activated $\mathrm{TiO}_{2}$ surface, comprising a less reactive carbonate $\left(\mathrm{CO}_{3}{ }^{\circ}\right)$ radical, slowing the degradation and mineralization process. Samples prepared at neutral $\mathrm{pH}$ exhibit more surface area and higher reactivity than those prepared at lower and higher $\mathrm{pH}$. Photocatalytic degradation process for optimum operational conditions was explained.

\subsection{Photodegradation Mechanisms of Magnetic $\mathrm{C} / \mathrm{TiO}_{2} / \mathrm{Ni}$} Nanocomposites. Overall, the mechanism of photocatalysis can be divided into five steps: (1) transfer of reactants in the fluid phase to the surface; (2) adsorption of the reactants; (3) reaction in the adsorbed phase; (4) desorption of the products; and (5) removal of products from the interface region [37]. A photocatalyst is a substance that, after being irradiated by light, can induce a chemical reaction in such a way that the actual substance of the catalyst will not be consumed [38]. It is well known that the photocatalytic activity could be controlled by varieties of factors such as surface area, phase structure, interfacial charge transfer, and separation efficiency of photoinduced electrons and holes. In this work, PAC molecule, acting as an electron shuttle, was mostly in contact with the surface of $\mathrm{TiO}_{2} / \mathrm{Ni}$ composite so that it could effectively transfer the photoelectrons from conduction band of $\mathrm{TiO}_{2} / \mathrm{Ni}$ composite after being illuminated under UV light irradiation. Therefore, the photogenerated electrons in the magnetic $\mathrm{C} / \mathrm{TiO}_{2} / \mathrm{Ni}$ photocatalyst could easily migrate from the inner region to the surface to take part in the surface reaction. A new magnetic $\mathrm{TiO}_{2}$-based photocatalyst combined with PAC and $\mathrm{Ni}$ is that which was prepared through a facile pyrolysis reaction [9]. Such series magnetic photocatalysts can be easily recycled from the aqueous solution because of the soft magnetism feature of combined Ni particles. The photocatalytic performance and the enhanced photocatalytic mechanism occurred on the interface of $\mathrm{C}-\mathrm{TiO}_{2}$ [9]. The storing and shuttling photoinduced electrons role of PAC in a photocatalytic process is realized by contacting the surface of $\mathrm{TiO}_{2}$ with the nanoparticles of PAC. It is the electronic contact between $\mathrm{TiO}_{2}$ and PAC that leads to the efficient separation of electron-hole pairs to reduce electron-hole recombination, which performs high photocatalytic activity under UV light irradiation [3941]. The mechanism of photodegradation of polyphenols, $\mathrm{COD}$, and TAAs on $\mathrm{C} / \mathrm{TiO}_{2} / \mathrm{Ni}$ nanocomposite surface was as follows. The excitation of $\mathrm{C} / \mathrm{TiO}_{2} / \mathrm{Ni}$ nanocomposite by solar energy leads to the formation of an electron-hole pair. The 
hole combines with water $\left(\mathrm{H}_{2} \mathrm{O}\right)$ to form hydroxyl radicals $\left(\mathrm{OH}^{\bullet}\right)$ while electron converts oxygen $\left(\mathrm{O}_{2}\right)$ to superoxide radical $\left(\mathrm{O}_{2}{ }^{-}\right)$, a strong oxidizing species as shown in the following:

magnetic $\mathrm{C} / \mathrm{TiO}_{2} / \mathrm{Ni}$ nanocomposite $+h v$

$\rightleftharpoons$ magnetic $\mathrm{C} / \mathrm{TiO}_{2} / \mathrm{Ni}$ nanocomposite $+h_{\mathrm{VB}}^{+}+e_{\mathrm{CB}}^{-}$

magnetic $\mathrm{C} / \mathrm{TiO}_{2} / \mathrm{Ni}$ nanocomposite $+h v$

$\rightleftharpoons$ magnetic $\mathrm{C} / \mathrm{TiO}_{2} / \mathrm{Ni}$ nanocomposite $\left(h_{\mathrm{VB}}^{+}+e_{\mathrm{CB}}^{-}\right)$

magnetic $\mathrm{C} / \mathrm{TiO}_{2} / \mathrm{Ni}$ nanocomposite $\mid \mathrm{OH}^{-}+h_{\mathrm{VB}}^{+}$

$\longrightarrow$ magnetic $\mathrm{C} / \mathrm{TiO}_{2} / \mathrm{Ni}$ nanocomposite $\mid \mathrm{OH}^{\bullet}$

magnetic $\mathrm{C} / \mathrm{TiO}_{2} / \mathrm{Ni}$ nanocomposite $\mid \mathrm{OH}_{2}+h_{\mathrm{VB}}^{+}$

$\longrightarrow$ magnetic $\mathrm{C} / \mathrm{TiO}_{2} / \mathrm{Ni}$ nanocomposite $\mid \mathrm{OH}^{\bullet}+\mathrm{H}^{+}$

magnetic $\mathrm{C} / \mathrm{TiO}_{2} / \mathrm{Ni}$ nanocomposite $\mid \mathrm{OH}^{\bullet}+\mathrm{Red}_{\text {org }}$

$\longrightarrow \mathrm{Ox}_{\mathrm{org}} \longrightarrow$ photodegradation of OMW pollutants

$h_{\mathrm{VB}}^{+}+\operatorname{Red}_{\mathrm{org}} \longrightarrow \mathrm{Ox}_{\mathrm{org}}$

$\longrightarrow$ photodegradation of OMW pollutants

$$
\begin{gathered}
\mathrm{OH}^{\bullet}+\mathrm{OH}^{\bullet} \longrightarrow \mathrm{H}_{2} \mathrm{O}_{2} \\
\mathrm{H}_{2} \mathrm{O}_{2}\left(\text { or } 2 \mathrm{OH}^{\bullet}\right) \longrightarrow 2 \mathrm{H}^{+}+\mathrm{O}_{2}
\end{gathered}
$$

COD, polyphenols, and TAAs are degraded via photooxidation process by reacting with both $\mathrm{OH}^{\bullet}$ radicals and $h_{\mathrm{VB}}^{+}$(according to equations $(1) \rightarrow(2),(3) \rightarrow(4)$, and $(1) \rightarrow$ (5)). The $\mathrm{OH}^{\circ}$ shows electrophilic character and prefers to attack electron rich ortho- or paracarbon atoms of COD, polyphenols, and TAAs. This results in the formation of polyphenol metabolites (catechol, tyrosol, quercetin, caffeic acid, 4-methyl catechol, 2-PHE, and 3-PHE) from total phenol and TAAs metabolites 2,4,6-trimethylaniline, aniline, o-toluidine, o-anisidine, dimethylalanine, ethylbenzene, and durene [3,6-bis(dimethylamino)]\} from TAAs are formed with photodegradation process in the OMW under UV and sunlight irradiations, respectively. Radicals undergo further reaction with dissolved oxygen (DO) in the OMW to remove polyphenol metabolites (catechol, tyrosol, quercetin, caffeic acid, and 4-methyl catechol) and TAAs metabolites (2,4,6-trimethylaniline, aniline, o-toluidine, o-anisidine, and dimethylalanine) with simultaneous generation of hydrogen peroxide $\left(\mathrm{H}_{2} \mathrm{O}_{2}\right)$ and oxygen radicals $\left(\mathrm{O}_{2}{ }^{\circ}\right)$. The superoxide $\left(\mathrm{O}_{2}{ }^{\cdot-}\right)$ produces $\mathrm{H}_{2} \mathrm{O}_{2}$ and $\mathrm{O}_{2}$ again by disproportion, and generation of $\mathrm{OH}^{\bullet}$ radical accompanied with the production and consumption of $\mathrm{H}_{2} \mathrm{O}_{2}$.
When the electrons in $\mathrm{TiO}_{2}$ (anatase phase) are irradiated by UV rays they can be excited from the valence band to the conduction band to generate electron-hole pairs [42]. The holes created in the valence band can react with $\mathrm{H}_{2} \mathrm{O}$ molecules to give hydroxide radicals $\left(\mathrm{OH}^{\circ}\right)$ and the photogenerated electrons are sufficiently reduced to produce superoxide $\left(\mathrm{O}_{2}{ }^{-2}\right)$. The redox potential of the electron-hole pair permits $\mathrm{H}_{2} \mathrm{O}_{2}$ formation. Depending on the reaction conditions, the holes, $\mathrm{OH}^{\bullet}, \mathrm{O}_{2}{ }^{-2}, \mathrm{H}_{2} \mathrm{O}_{2}$, and $\mathrm{O}_{2}$, can play important roles in the photocatalytic reaction mechanism. There are several issues that are important in this process. First, exposing the external surface of $\mathrm{TiO}_{2}$ particles to light is a prerequisite to make such an excitement happen. Second, the light energy $(E=h v)$ must exceed the band gap $(3.20 \mathrm{eV})$ of the anatase-type $\mathrm{TiO}_{2}$; therefore lowering the band gap of $\mathrm{TiO}_{2}$ or using low wavelength light is needed to increase the light utilization efficiency. Third, the oxidizing species cannot migrate for a long distance and stay near the active centers in the $\mathrm{TiO}_{2}$ particles. Therefore, polluting molecules have to diffuse to the photoexcited active centers. Fourth, the recombination of positive holes with excited electrons before they react to create active species and centers has to be avoided.

Baransi et al. [33] reported that photodegradation of anaerobically treated and diluted (1/10) OMW by the combined $\mathrm{TiO}_{2}$-PAC sorbent was observed to the normalized concentration of $100 \mathrm{mg} \mathrm{L}^{-1}$ caffeic acid which was operated during the three successive runs. In the first run, an instantaneous and high adsorption of caffeic acid was observed both on the mixture of $\mathrm{TiO}_{2} / \mathrm{PAC}$ and on the pure $0.45 \mathrm{~g} \mathrm{~L}^{-1}$ PAC (95\% caffeic acid removal within $15 \mathrm{~min}$ ), at $\mathrm{pH}=4.1$, at $50 \mathrm{~mL} \mathrm{OMW,} \mathrm{at} 25^{\circ} \mathrm{C}$, at $365 \mathrm{~nm} \mathrm{UV} \mathrm{light} \mathrm{(at} 7.6 \mathrm{~W} \mathrm{~m}^{-2}$ ) irradiation. The instantaneous adsorption of the caffeic acid on $3 \mathrm{gL}^{-1} \quad \mathrm{TiO}_{2}$ alone was much lower (40\% caffeic acid removal within $15 \mathrm{~min}$ ), but continuous adsorption and photocatalysis processes led to $95 \%$ caffeic acid removal after $24 \mathrm{~h}$, at $\mathrm{pH}=4.1$, at $50 \mathrm{~mL} \mathrm{OMW}$, at $25^{\circ} \mathrm{C}$, at UV light. Direct photolysis (in the absence of catalyst or adsorbent) resulted in removal of only $17 \%$ of initial caffeic acid within $24 \mathrm{~h}$, at $\mathrm{pH}=4.1$, at $50 \mathrm{~mL} \mathrm{OMW}$, at $25^{\circ} \mathrm{C}$, at UV light [33]. In this study, $86 \%$ caffeic acid removal found under $300 \mathrm{~W}$ UV light, after $60 \mathrm{~min}$, at $25^{\circ} \mathrm{C}$, at $\mathrm{pH}=7.0$, is higher than the removal observed by Baransi et al. [33] as mentioned above.

\section{Conclusions}

In this study, we examined the photodegradation of pollutant parameters (COD components, polyphenols, and TAAs metabolites) in the OMW under UV and sunlight irradiations, with $\mathrm{C} / \mathrm{TiO}_{2} / \mathrm{Ni}$ nanocomposites, at optimum operational conditions. The maximum removals of pollutant parameters (COD components, polyphenols and TAAs metabolites) in the OMW reached, under $300 \mathrm{~W}$ UV and $30 \mathrm{~W}$ sunlight, at $500 \mathrm{mg} \mathrm{L}^{-1} \mathrm{C} / \mathrm{TiO}_{2} / \mathrm{Ni}$ nanocomposite concentration, at a mass ratio of $2 \% / 5 \% / 1 \%$, at $\mathrm{pH}=7.0$, at $25^{\circ} \mathrm{C}$, after $60 \mathrm{~min}$. $\mathrm{C} / \mathrm{TiO}_{2} / \mathrm{Ni}$ nanocomposite is suitable for photodegradation of polyphenols and TAAs metabolites in the OMW. The high removal efficiency obtained with $\mathrm{C} / \mathrm{TiO}_{2} / \mathrm{Ni}$ 
nanoparticule qualifies that this effect may be caused by the synergetic effect on the interface of $\mathrm{TiO}_{2} / \mathrm{Ni}$ and $\mathrm{PAC}$ that can promote the photoinduced electron mobility in the surface of $\mathrm{TiO}_{2}$ and the absorption of PAC particles that bring the high concentration of OMW around $\mathrm{TiO}_{2}$ particles. Providing such a combination could be a step toward the development of sustainable, reliable, and cost-effective technology for the treatment of agroindustrial wastewaters, which demonstrate high innate resistance to biodegradability.

\section{Conflict of Interests}

The authors declare that there is no conflict of interests regarding the publication of this paper.

\section{Acknowledgment}

This research study was undertaken in the Environmental Microbiology Laboratory at Dokuz Eylül University, Engineering Faculty, Environmental Engineering Department, İzmir, Turkey. The authors would like to thank this body for providing financial support.

\section{References}

[1] M. R. Hoffmann, S. T. Martin, W. Choi, and D. W. Bahnemann, "Environmental applications of semiconductor photocatalysis," Chemical Reviews, vol. 95, no. 1, pp. 69-96, 1995.

[2] M. A. Gondal, X. F. Chang, and Z. H. Yamani, "UV-light induced photocatalytic decolorization of Rhodamine $6 \mathrm{G}$ molecules over $\mathrm{BiOCl}$ from aqueous solution," Chemical Engineering Journal, vol. 165, no. 1, pp. 250-257, 2010.

[3] Z. Yi, J. Ye, N. Kikugawa et al., "An orthophosphate semiconductor with photooxidation properties under visible-light irradiation," Nature Materials, vol. 9, no. 1, pp. 559-564, 2010.

[4] U. G. Akpan and B. H. Hameed, "The advancements in solgel method of doped- $\mathrm{TiO}_{2}$ photocatalysts," Applied Catalysis A: General, vol. 375, no. 1, pp. 1-11, 2010.

[5] P. P. Bidaye, D. Khushalani, and J. B. Fernandes, "A simple method for synthesis of S-doped $\mathrm{TiO}_{2}$ of high photocatalytic activity," Catalysis Letters, vol. 134, no. 1-2, pp. 169-174, 2010.

[6] A. I. Kontos, V. Likodimos, T. Stergiopoulos et al., "Selforganized anodic $\mathrm{TiO}_{2}$ nanotube arrays functionalized by iron oxide nanoparticles," Chemistry of Materials, vol. 21, no. 4, pp. 662-672, 2009.

[7] X. Chang, J. Huang, Q. Tan et al., "Photocatalytic degradation of PCP-Na over BiOI nanosheets under simulated sunlight irradiation," Catalysis Communications, vol. 10, no. 15, pp. 19571961, 2009.

[8] X. Chang, G. Ji, Q. Sui, J. Huang, and G. Yu, "Rapid photocatalytic degradation of PCP-Na over $\mathrm{NaBiO}_{3}$ driven by visible light irradiation," Journal of Hazardous Materials, vol. 166, no. 2-3, pp. 728-733, 2009.

[9] M. A. Gondal, C. Li, X. Chang et al., "Facile preparation of magnetic $\mathrm{C} / \mathrm{TiO}_{2} / \mathrm{Ni}$ composites and their photocatalytic performance for removal of a dye from water under UV light irradiation," Journal of Environmental Science and Health Part A: Toxic/Hazardous Substances and Environmental Engineering, vol. 47, no. 4, pp. 570-576, 2012.
[10] X. Shao, W. Lu, R. Zhang, and F. Pan, "Enhanced photocatalytic activity of $\mathrm{TiO}_{2}-\mathrm{C}$ hybrid aerogels for methylene blue degradation," Scientific Reports, vol. 3, article 3018, 2013.

[11] D. Zhang, "Chemical synthesis of $\mathrm{Ni} / \mathrm{TiO}_{2}$ nanophotocatalyst for UV/visible light assisted degradation of organic dye in aqueous solution," Journal of Sol-Gel Science and Technology, vol. 58, no. 1, pp. 312-318, 2011.

[12] W. Lin, H. Cheng, J. Ming, Y. Yu, and F. Zhao, "Deactivation of $\mathrm{Ni} / \mathrm{TiO}_{2}$ catalyst in the hydrogenation of nitrobenzene in water and improvement in its stability by coating a layer of hydrophobic carbon," Journal of Catalysis, vol. 291, no. 1-2, pp. 149-154, 2012.

[13] A. Pirkarami, M. E. Olya, and S. Raeis Farshid, "UV/Ni-TiO 2 nanocatalyst for electrochemical removal of dyes considering operating costs," Water Resources and Industry, vol. 5, pp. 9-20, 2014.

[14] N. Xu, Z. Shi, Y. Fan, J. Dong, J. Shi, and M. Z.-C. Hu, "Effects of particle size of $\mathrm{TiO}_{2}$ on photocatalytic degradation of methylene blue in aqueous suspensions," Industrial and Engineering Chemistry Research, vol. 38, no. 2, pp. 373-379, 1999.

[15] P. Zeng, X. Zhang, B. Chai, and T. Peng, "Efficient photocatalytic hydrogen production over $\mathrm{Ni@C/TiO}$, nanocomposite under visible light irradiation," Chemical Physics Letters, vol. 503, no. 4-6, pp. 262-265, 2011.

[16] M. Achak, N. Ouazzani, A. Yaacoubi, and L. Mandi, "Caractérisation des margines issues d'une huilerie moderne et essais de leur traitement par coagulation-floculation par la chaux et le sulfate d'aluminium," Revue des Sciences de l'Eau, vol. 21, no. 1, pp. 53-67, 2008.

[17] M. Achak, L. Mandi, and N. Ouazzani, "Removal of organic pollutants and nutrients from olive mill wastewater by a sand filter," Journal of Environmental Management, vol. 90, no. 8, pp. 2771-2779, 2009.

[18] M. Achak, N. Ouazzani, and L. Mandi, "Treatment of modern olive mill effiuent by infiltration-percolation on a sand filter," Revue des Sciences de l'Eau, vol. 22, no. 3, pp. 421-433, 2009.

[19] O. Chedeville, M. Debacq, and C. Porte, "Removal of phenolic compounds present in olive mill wastewaters by ozonation," Desalination, vol. 249, no. 2, pp. 865-869, 2009.

[20] C. A. Paraskeva, V. G. Papadakis, E. Tsarouchi, D. G. Kanellopoulou, and P. G. Koutsoukos, "Membrane processing for olive mill wastewater fractionation," Desalination, vol. 213, no. 1-3, pp. 218-229, 2007.

[21] H. Dhaouadi and B. Marrot, "Olive mill wastewater treatment in a membrane bioreactor: process feasibility and performances," Chemical Engineering Journal, vol. 145, no. 2, pp. 225-231, 2008.

[22] E. O. Akdemir and A. Ozer, "Investigation of two ultrafiltration membranes for treatment of olive oil mill wastewater," Desalination, vol. 249, no. 2, pp. 660-666, 2009.

[23] Ç. Y. Gomec, E. Erdim, I. Turan, A. F. Aydin, and I. Ozturk, "Advanced oxidation treatment of physico-chemically pretreated olive mill industry effluent," Journal of Environmental Science and Health Part B, vol. 42, no. 6, pp. 741-747, 2007.

[24] A. A. Zorpas and C. N. Costa, "Combination of Fenton oxidation and composting for the treatment of the olive solid residue and the olive mile wastewater from the olive oil industry in Cyprus," Bioresource Technology, vol. 101, no. 20, pp. 79847987, 2010.

[25] N. Azbar, T. Keskin, and E. C. Catalkaya, "Improvement in anaerobic degradation of olive mill effluent (OME) by chemical pretreatment using batch systems," Biochemical Engineering Journal, vol. 38, no. 3, pp. 379-383, 2008. 
[26] N. Azbar, T. Keskin, and A. Yuruyen, "Enhancement of biogas production from olive mill effluent (OME) by co-digestion," Biomass and Bioenergy, vol. 32, no. 12, pp. 1195-1201, 2008.

[27] F. Boubaker and B. C. Ridha, "Modelling of the mesophilic anaerobic co-digestion of olive mill wastewater with olive mill solid waste using anaerobic digestion model No. 1 (ADM1)," Bioresource Technology, vol. 99, no. 14, pp. 6565-6577, 2008.

[28] Y. Ruzmanova, M. Stoller, and A. Chianese, "Photocatalytic treatment of olive mill wastewater by magnetic core titanium dioxide nanoparticles," Chemical Engineering Transactions, vol. 32, pp. 2269-2274, 2013.

[29] J. M. Ochando-Pulido, G. Hodaifa, M. D. Víctor-Ortega, and A. Martínez-Ferez, "A novel photocatalyst with ferromagnetic core used for the treatment of olive oil mill effluents from twophase production process," The Scientific World Journal, vol. 2013, Article ID 196470, 9 pages, 2013.

[30] A. D. Eaton, L. S. Clesceri, E. W. Rice, A. E. Greenberg, and M. A. H. Franson, Standard Methods for the Examination of Water and Wastewater, American Public Health Association (APHA), American Water Works Association (AWWA), Water Environment Federation (WEF), American Public Health Association (APHA), Washington, DC, USA, 21th edition, 2005.

[31] F. Germirli, D. Orhon, and N. Artan, "Assessment of the initial inert soluble COD in industrial wastewaters," Water Science and Technology, vol. 23, no. 4-6, pp. 1077-1086, 1991.

[32] H. Pang, Y. Li, L. Guan, Q. Lu, and F. Gao, “ $\mathrm{TiO}_{2} / \mathrm{Ni}$ nanocomposites: biocompatible and recyclable magnetic photocatalysts," Catalysis Communications, vol. 12, no. 7, pp. 611-615, 2011.

[33] K. Baransi, Y. Dubowski, and I. Sabbah, "Synergetic effect between photocatalytic degradation and adsorption processes on the removal of phenolic compounds from olive mill wastewater," Water Research, vol. 46, no. 3, pp. 789-798, 2012.

[34] A. G. Rincón and C. Pulgarin, "Photocatalytical inactivation of E. coli: effect of (continuous-intermittent) light intensity and of (suspended-fixed) $\mathrm{TiO}_{2}$ concentration," Applied Catalysis B: Environmental, vol. 44, no. 3, pp. 263-284, 2003.

[35] E. Evgenidou, K. Fytianos, and I. Poulios, "Semiconductorsensitized photodegradation of dichlorvos in water using $\mathrm{TiO}_{2}$ and $\mathrm{ZnO}$ as catalysts," Applied Catalysis B: Environmental, vol. 59, no. 1-2, pp. 81-89, 2005.

[36] U. I. Gaya and A. H. Abdullah, "Heterogeneous photocatalytic degradation of organic contaminants over titanium dioxide: a review of fundamentals, progress and problems," Journal of Photochemistry and Photobiology C: Photochemistry Reviews, vol. 9, no. 1, pp. 1-12, 2008.

[37] J.-M. Herrmann, C. Duchamp, M. Karkmaz et al., "Environmental green chemistry as defined by photocatalysis," Journal of Hazardous Materials, vol. 146, no. 3, pp. 624-629, 2007.

[38] S. Gelover, P. Mondragón, and A. Jiménez, “Titanium dioxide sol-gel deposited over glass and its application as a photocatalyst for water decontamination," Journal of Photochemistry and Photobiology A: Chemistry, vol. 165, no. 1-3, pp. 241-246, 2004.

[39] S. Zhu, T. Xu, H. Fu, J. Zhao, and Y. Zhu, "Synergetic effect of $\mathrm{Bi}_{2} \mathrm{WO}_{6}$ photocatalyst with $\mathrm{C}_{60}$ and enhanced photoactivity under visible irradiation," Environmental Science and Technology, vol. 41, no. 17, pp. 6234-6239, 2007.

[40] Y. Zhang, Z.-R. Tang, X. Fu, and Y.-J. Xu, “ $\mathrm{TiO}_{2}$-graphene nanocomposites for gas-phase photocatalytic degradation of volatile aromatic pollutant: is $\mathrm{TiO}_{2}$-graphene truly different from other $\mathrm{TiO}_{2}$-carbon composite materials?" ACS Nano, vol. 4, no. 12, pp. 7303-7314, 2010.
[41] H. Zhang, X. Lv, Y. Li, Y. Wang, and J. Li, "P25-graphene composite as a high performance photocatalyst," ACS Nano, vol. 4, no. 1, pp. 380-386, 2010.

[42] O. Carp, C. L. Huisman, and A. Reller, "Photoinduced reactivity of titanium dioxide," Progress in Solid State Chemistry, vol. 32, no. 1-2, pp. 33-177, 2004. 

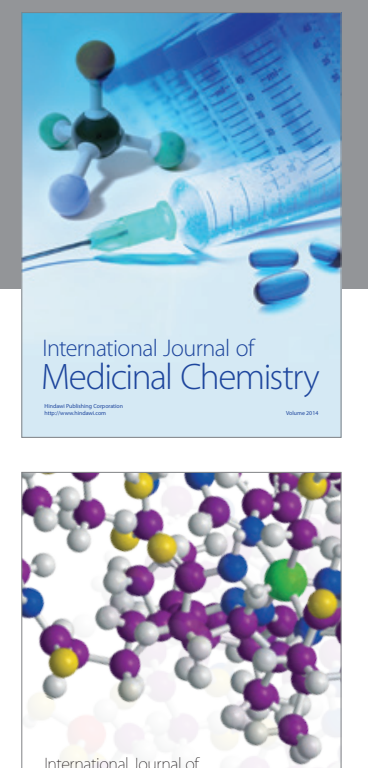

\section{Carbohydrate} Chemistry

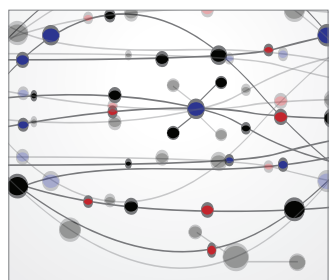

The Scientific World Journal
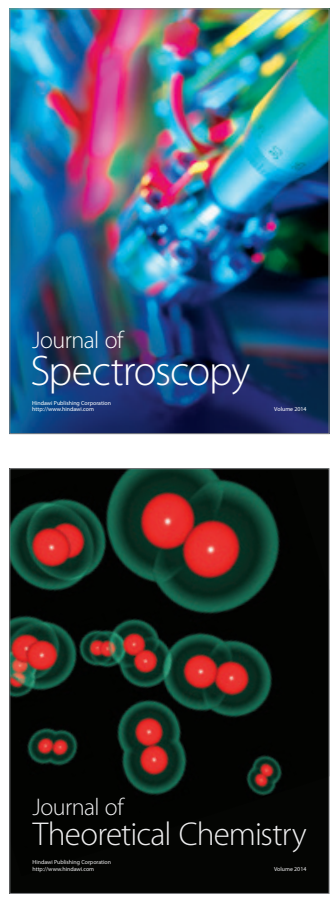
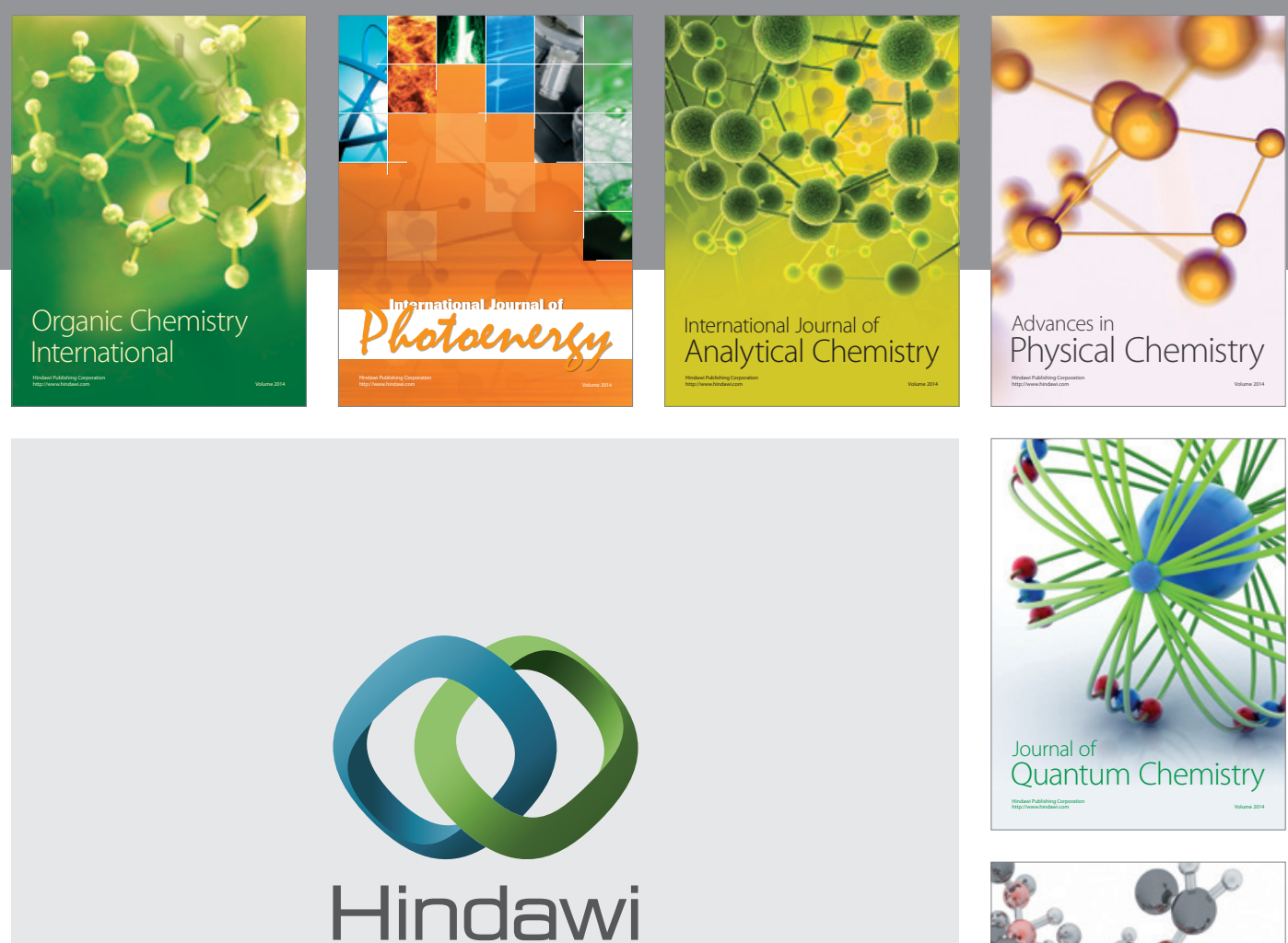

Submit your manuscripts at

http://www.hindawi.com

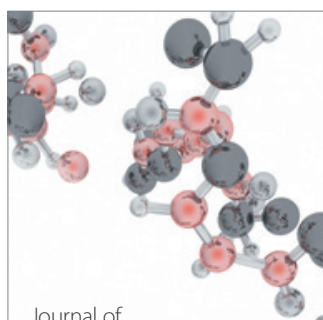

Analytical Methods

in Chemistry

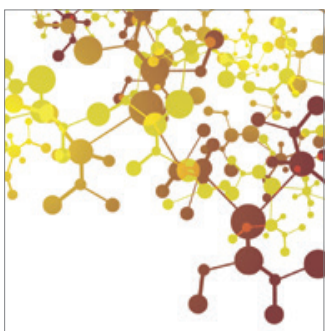

Journal of

Applied Chemistry

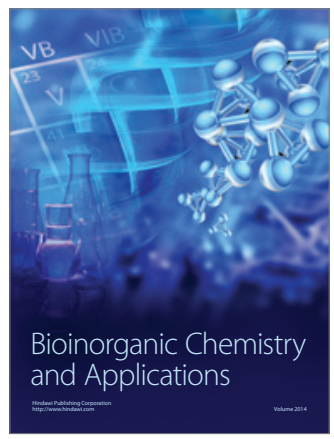

Inorganic Chemistry
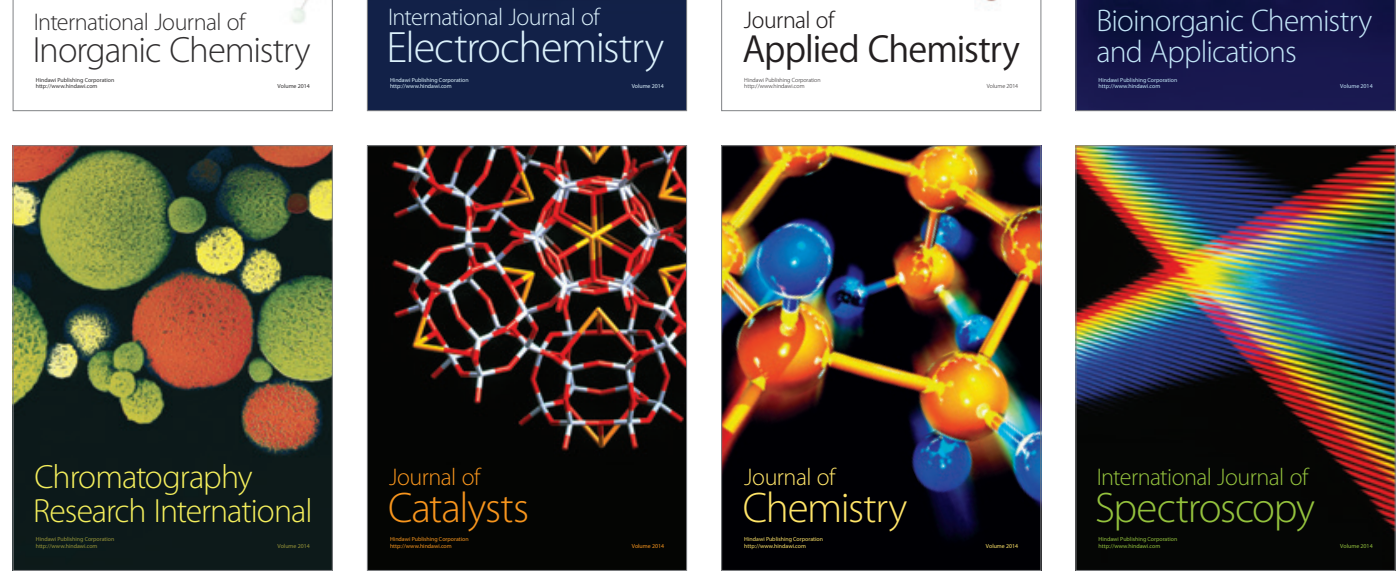